\title{
Szlachcic w domu. \\ Wystrój i wyposażenie siedzib szlacheckich w ziemi zakroczymskiej w drugiej połowie XVII i w XVIII wieku
}

\begin{abstract}
Abstrakt: W artykule scharakteryzowano przedmioty wymienione w 238 spisach ruchomości z lat 1677-1795, znajdujących się w księgach kancelarii sądu grodzkiego zakroczymskiego. Wyroby te stanowiły wystrój i wyposażenie domów szlachty w ziemi zakroczymskiej na Mazowszu. Zestaw przedmiotów, z których wewnątrz siedziby codziennie korzystał właściciel i jego najbliższa rodzina, był podobny do znanego z innych środowisk społecznych i innych regionów Rzeczypospolitej. Elementem różnicującym, podkreślającym status społeczny, były: surowce, kolorystyka, wykończenie i zdobienie oraz liczba rzeczy. Wskazano pewne tendencje czytelne w badanym okresie, m.in. stopniowy zanik tradycyjnych elementów wnętrz (takich jak tkaniny orientalne), w drugiej połowie XVIII w. częstsze stosowanie parawanów, pawilonów przy łóżkach, zwiększenie średniej liczby kufrów, bielizny stołowej i zastawy stołowej, a także pojawienie się, chociaż jeszcze w ograniczonym zakresie, meblarskich nowinek (np. stołów okrągłych lub składanych, garniturów złożonych z kanapy i krzeseł, komody), używanie naczyń z fajansu i porcelany.
\end{abstract}

Abstract: The article characterises the objects listed in 238 lists of movables from the years $1677-1795$ recorded in the registers from the chancellery of the Zakroczym nobility court. These items constituted the decor and furnishings of the houses of the nobility in the Zakroczym Land in Mazovia. The set of objects, which were used daily inside the residences by the owners and their closest family, was similar to that known from other social environments and other regions of the Commonwealth of Poland. The differentiating elements, emphasising the social status, were: raw materials, colours, finishing, and ornamentation, as well as the quantity of items. The article indicates certain tendencies that were readily apparent in the analysed period, including the gradual disappearance of traditional elements of interior decoration (such as oriental textiles) and in the second half of the 18th century more frequent use of screens, canopy beds, an increase in the average number of chests, table linen, and tableware, as well as the arrival (although still on a limited scale) of furniture novelties (for instance, round or folding tables, suits consisting of a sofa and chairs, chests of drawers), and use of faïence and porcelain vessels.

Słowa kluczowe: inwentarze pośmiertne, materialne warunki bytu, siedziby szlachty, szlachta, Mazowsze

Key words: probate inventories, living conditions, noble residences, nobility, Mazovia

W artykule o siedzibach szlacheckich w ziemi zakroczymskiej z 2018 r. ${ }^{1}$ podstawą rozważań były inwentarze dóbr ziemskich z lat 1668-1787. Ten typ przekazów bywa pomocny także w omówieniu zagadnień określonych w tytule ${ }^{2}$. Jednakże w znanych mi danych dla badanego regionu

\footnotetext{
${ }^{1}$ Główka D. 2018.

2 Por. też: Dumanowski J. 2006, s. 46; Pielas J. 2018.
} 
o ruchomościach, stanowiących elementy wystroju i wyposażenia domów, wiadomości jest niewiele. Tylko parokrotnie wspomniano meble. W opisie dworu w Dzbanicach w 1727 r. odnotowano „stół sosnowy, obrazy 3, krucyfiks, stołków 12, krzeseł starych 2, łóżka 2; w starym dworze okien 3, piec prosty, szafa, magiel, stół”3. Jeszcze mniej sprzętów, bo tylko „stół, szafa”, zostało uwzględnionych w opisie majętności należącej w 1777 r. do Andrzeja Klukowskiego ${ }^{4}$. Dlatego też, w celu realizacji podstawowego zamierzenia, $\mathrm{tj}$. przeprowadzenia bardziej rozbudowanych analiz dotyczących wnętrz dworów szlacheckich i znajdującego się tam dobytku, przechowywanego i użytkowanego przez właściciela i jego rodzinę, niezbędne było spożytkowanie informacji zawartych także w spisach ruchomości, przede wszystkim zaś w inwentarzach pośmiertnych.

W wyniku kwerendy w księgach kancelarii sądu grodzkiego zakroczymskiego (grodzkich wieczystych, grodzkich relacji, relationum oraz ziemskich wieczystych relacji) odnaleziono 238 spisów ruchomości różnego typu, w tym: 205 inwentarzy pośmiertnych, 17 spisów wypraw ślubnych oraz 16 innych rejestrów, pochodzących z okresu od 1677 do 1795 r. Stanowiły one podstawę źródłową niniejszego opracowania.

Chronologia zakroczymskich spisów inwentarzowych pokazuje, że na omawianym terenie inwentarz wyliczający ruchomości do końca XVII w. był rzadko stosowanym instrumentem prawnym. Dopiero w latach osiemdziesiątych tego stulecia, zamiast trzech, jak to bywało we wcześniejszych dziesięcioleciach, spisano siedem inwentarzy, zaś w ostatnim dziesięcioleciu aż 22. Ten wzrost pokrywa się z ustaleniami Andrzeja Pośpiecha dla Wielkopolski — tam także na lata 1690-1699 przypada aż 38\% spisów w skali całego wieku 5 .

Nie wszystkie uwzględnione dokumenty zawierają dane przydatne do analizy tytułowych kwestii. Na przykład, w 1695 r. wdowa Katarzyna Gawłowska spisała „Inwentarz rzeczy ruchomych po nieboszczyku Franciszku Gawłowskim pozostałych”. Po opisie wyglądu skromnego domu wymieniono: „kontusz granatowy paklakowy, dałam szwagrowi, żupan stary, czapka, szabla. Kłód 5, skrzynka, spiżarnia, toki 2, inne sprzęty domowe są własne moje i synów moich" "Zestaw wyliczonych przedmiotów jest dość skromny. Nie wiadomo, jakie ruchomości nie zostały spisane i, można by rzec, ukryto je w sferze prywatności, wyznaczonej słowami kończącymi powyższy fragment. Warto zacytować dwa inne inwentarze powstałe w sytuacji nietypowej, która rzutowała na ich zawartość. Zdanie: ,sprzęt domowy, który po nieboszczyku został wszystek zgorzał exceptis żelas płużnych, lemiesz jeden, siekier dwie” pochodzi z dokumentu zatytułowanego „Inwentarz spisany po zeyściu nieboszczyka P. Sebastiana Kamieńskiego” z 1677 r. ${ }^{7}$ „Regestr spisany wszystkiego gospodarstwa [...] śp. Adamie Żebrowskim na Gnatach Wienianach" powstał 1 lutego 1722 r. Wdowa Eufrozyna z Górskich odnotowała w dokumencie dwa woły sprzedane na pokrycie kosztów pogrzebu, kurę, świnię oraz „kłód dwie do zboża, tok, koryto, siekier dwie, świdrów dużych dwa, dłuto jedno, świdrów małych dwa, sierpów trzy, rożen, klamra, żelazo do kosy klepania para jedna, owiec trzy, inszych rzeczy nie piszę, bo razem wszystkie pogorzały z budynkiem"s. Prawdopodobnie pożar strawił tylko dom mieszkalny, a wymienione narzędzia oraz inwentarz żywy znajdowały się w innym, nieobjętym pożarem miejscu.

W związku z tym do prezentowanych poniżej analiz i opisów użyte zostały 164 przekazy źródłowe, w tym: 29 z drugiej połowy XVII w., 71 z pierwszej połowy XVIII stulecia oraz 59 z drugiej połowy tegoż wieku. Liczba akt z poszczególnych dziesięcioleci była różna. Najwię-

\footnotetext{
3 AGAD, zakr. gr. rel., 25, k. 365.

${ }^{4}$ AGAD, ziem. wiecz. rel., 109, k. 287.

5 Pośpiech A. 1992a, s. 32.

${ }^{6}$ AGAD, zakr. gr. rel., 108, k. 68.

7 AGAD, zakr. gr. wiecz., 81, k. 269.

${ }^{8}$ AGAD, zakr. rel., 10, k. 29.
} 
cej (bo po 30) pochodzi z lat dwudziestych i czterdziestych XVIII w., a najmniej (poniżej 10) oblatowano spisów w latach trzydziestych oraz osiemdziesiątych, a także w ostatnim, niepełnym dziesięcioleciu, u kresu pierwszej Rzeczypospolitej.

Tabela 1.

Liczba obić ściennych w analizowanych źródłach

Table 1

Number of wall coverings in the analysed sources

\begin{tabular}{|l|c|c|c|c|c|}
\hline \multicolumn{1}{|c|}{ Lata } & $\begin{array}{c}\text { Liczba przekazów } \\
\text { ogółem }\end{array}$ & $\begin{array}{c}\text { Liczba sztuk } \\
\text { obić ściennych }\end{array}$ & $\begin{array}{c}\text { Liczba } \\
\text { przekazów }\end{array}$ & $\begin{array}{c}\text { Procent } \\
\text { przekazów }\end{array}$ & Średnio \\
\hline $1651-1700$ & 29 & 6 & 2 & 6,90 & 3,00 \\
\hline $1701-1750$ & 71 & 10 & 6 & 8,45 & 1,67 \\
\hline $1751-1800$ & 59 & 24 & 17 & 28,81 & 1,41 \\
\hline Razem & 164 & 40 & 25 & 15,24 & 1,60 \\
\hline
\end{tabular}

W zakresie dekoracji wnętrz mieszkalnych najpowszechniejszym sposobem zdobienia drewnianych ścian szlacheckich domostw było zawieszanie na nich różnorakich obić. Były to przede wszystkim tkaniny określane jako ,perskie" 1 , „tureckie"10 (tab. 1). Ta tradycyjna moda na posiadanie przedmiotów pochodzących ze Wschodu, a przynajmniej je imitujących, wydaje się w badanym okresie ciągle atrakcyjna dla prowincjonalnej szlachty. Niektóre opisy wskazują jednak na znaczne zniszczenie materiałów, np. „obicie stare perskie całe jeszcze oprócz od myszy podziurawione" odnotowane w 1776 r. w inwentarzu pośmiertnym stolnika gostyńskiego Tomasza Stawińskiego ${ }^{11}$. Podobnie w regestrze spisanym w 1770 r. po śmierci Antoniego Łazowskiego przez brata stryjecznego Łukasza, zaznaczono, że obicie ,czerwone materii tureckiej w słupów 8 częściowo czerwone częścią białe wyszywane płotnem podszyte miejscami naprawiane miejscami dziury" ${ }^{\prime 2}$. W drugiej połowie XVIII w. wymieniano także obicia z tkanin zdobionych techniką druku ręcznego (z drewnianego klocka) ${ }^{13}$. Uważane są za tańsze, tym niemniej ich użycie świadczy o sięganiu — oczywiście pośrednio — po zachodnioeuropejskie wzorce urządzania wnętrz. W ten sposób ozdobione były oba pokoje w domach kapitana gwardii saskiej Antoniego Osieckiego oraz starościca mścisławskiego Krzysztofa Wołłowicza, a także w Jackowie należącym do majora regimentu łanowego koronnego Czesława Ignacego Łempickiego. Wdowa po starościcu Marianna z Mokrskich nie omieszkała zauważyć, że było ono „nowe [i — D.G.] kosztuje zł. 200 ”.14. Obicie w jednym z pokoi w Jackowie było ,czerwono z zielonym drukowane”, w drugim „niebieskie w pasy”, zaś w trzecim miało bardziej tradycyjny charakter, gdyż określono je jako „,półatłasowe w pasy na jeden pokój”"15. Jeszcze tylko raz — w 1785 r., pośród ruchomości stolnika sanockiego Mateusza Guzkowskiego - wymieniono obicie z drogiej tkaniny, opisane jako

9 Odnotowano je sześciokrotnie w latach 1743-1787, AGAD, zakr. grodz. rel., 42, k. 1v (1746 r.); 52 , k. 505-506v (1755 r.); 59, k. 387v (1769 r.); 84, k. 168 (1787 r.); AGAD, zakr. ziem. wiecz. rel., 109, k. 516 (1776 r.); zakr. grodz. wiecz., 117, k. 278v (1743 r.).

${ }_{10} \mathrm{~W}$ latach 1677-1791 wymieniono je w pięciu przekazach, AGAD, zakr. grodz. rel., 5, k. 460v (1677 r.); 25, k. 144c (1726 r.); 66, k. 631v (1770 r.); 82, k. 593 (1785 r.); 87, k. 152v (1791 r.).

${ }^{11}$ AGAD, zakr. ziem. wiecz. rel., 109, k. 516.

12 AGAD, zakr. grodz. rel., 66, k. 631v.

13 W latach 1750-1771 wspomniano o nich w trzech aktach: AGAD, zakr. grodz. rel., 46, k. $96 \mathrm{v}$ (1750 r.); 66, k. 712 v (1771 r.); 66, k. 741 (1771 r.).

${ }^{14}$ AGAD, zakr. grodz. rel., 66, k. 712v (1771 r.).

15 AGAD, zakr. grodz. rel., 66, k. 741 (1771 r.). 
„półjedwabne zielone brytów 11”16. Rzadziej wzmiankowano obicia malowane ${ }^{17}$ lub papierowe ${ }^{18}$. Niekiedy zaznaczano kolory obić; wybierano zieleń ${ }^{19}$ oraz czerwien ${ }^{20}$. Niezmiernie rzadko notowano użycie firanek do ozdoby okien ${ }^{21}$ lub zasłon (kotar ?) przy drzwiach ${ }^{22}$.

Tabela 2.

Liczba kobierców w analizowanych źródłach

Table 2

Number of carpets in the analysed sources

\begin{tabular}{|l|c|c|c|c|c|}
\hline \multicolumn{1}{|c|}{ Lata } & $\begin{array}{c}\text { Liczba przekazów } \\
\text { ogółem }\end{array}$ & $\begin{array}{c}\text { Liczba sztuk } \\
\text { kobierców }\end{array}$ & $\begin{array}{c}\text { Liczba } \\
\text { przekazów }\end{array}$ & $\begin{array}{c}\text { Procent } \\
\text { przekazów }\end{array}$ & Średnio \\
\hline $1651-1700$ & 29 & 23 & 8 & 27,59 & 2,88 \\
\hline $1701-1750$ & 71 & 27 & 14 & 19,72 & 1,93 \\
\hline $1751-1800$ & 59 & 10 & 7 & 11,86 & 1,43 \\
\hline Razem & 164 & 60 & 29 & 17,68 & 2,07 \\
\hline
\end{tabular}

Zgodnie z tradycyjnym stylem urządzania wnętrz, na niektórych typach mebli kładziono bądź na ścianach zawieszano kobierce, kilimy, dywany i makaty. Dominowały wzmianki o kobiercach, głównie w drugiej połowie XVII w., nieco rzadziej zaś w pierwszej połowie XVIII stulecia. Być może z czasem były one zastępowane przez obicia (tab. 2). Zdecydowaną ich większość opisano jako stare ${ }^{23}$, rzadko zaś jako nowe ${ }^{24}$. Tylko dwukrotnie sprecyzowano, że leżały na stołach ${ }^{25}$. Sporadycznie nadmieniono też o ich orientalnym pochodzeniu, określając je jako „perskie”26. Sporo, bo sześć tych wyrobów, miał zmarły w 1677 r. podkomorzy chełmiński i generał autoramentu cudzoziemskiego Krzysztof Korycki ${ }^{27}$. Wojciech Lubecki, pisarz konsystorza pułtuskiego i prepozyt w Dzierżeninie, w 1743 r. na trzy czerwone złote wycenił kobierzec należący do Anny Łatynowej z Lubeckich. Z kolei na pięć czerwonych złotych oszacował parę kilimów ${ }^{28}$. Tańszy, wart 5 zł, spisano w 1701 r. w inwentarzu pośmiertnym niejakie-

${ }^{16}$ Miał on także obicie „tureckie stare na białym dnie z kolorami różnymi w bretach czternastu” oraz „płócienne na grygrynowym dnie na pokój cały duży i na mały pokój”, AGAD, zakr. grodz. rel., 82, k. 593v.

17 Tylko dwukrotnie odnotowano je wśród rzeczy: Franciszka Mieszkowskiego, AGAD, zakr. grodz. rel., 62, k. 370v (1760 r.) oraz Mateusza Tańskiego, AGAD, zakr. grodz. rel., 67, k. 238 (1765 r.).

18 Wspomniane w 1771 r. w spuściznie po śmierci Franciszka Miecznikowskiego, AGAD, zakr. ziem. wiecz. rel., 109, k. 382.

${ }_{19}$ AGAD, zakr. grodz. rel., 49, k. 432v (1750 r.); 65, k. 60 (1759 r.); 44, k. 58 (1751 r.); 82, k. 593v (1785 r.).

${ }^{20}$ AGAD, zakr. grodz. rel., 5, k. 460v (1677 r.); 36, k. 235a-v (1741 r.).

${ }^{21}$ Firanki wspomniano w pięciu przekazach z lat 1726-1795, łącznie 18, niemal wyłącznie płóciennych: AGAD, zakr. grodz. rel., 25, k. 144 c (1726 r.); 66, k. 741 (1771 r.); 66, k. 761v (1772 r.); 79, k. 903v (1783 r.), AGAD, zakr. ziem. wiecz. rel., 112, k. 252 (1795 r.).

${ }_{22}$ Wspomniano je tylko jeden raz, jako ,zasłony ode drzwi sukienne dwie stare niebieskie” w inwentarzu pośmiertnym stolnika nowogrodzkiego, Franciszka Czaczkowskiego w 1726 r., AGAD, zakr. grodz. rel., 25, k. $144 \mathrm{c}$.

2315 obić w 10 przekazach opisano jako stare: AGAD, zakr. grodz. wiecz.,108, k. 568v (1698 r.); AGAD, zakr. grodz. rel., 21, k. 24v (1718 r.); 22, k. 43 (1722 r.); 23, k. 164v (1723 r.); 36, k. 235a (1741 r.); 46, k. 96v (1750 r.); 52, k. 505-506v (1753 r.); 66, k. 712v (1771 r.); 81, k. 160v (1785 r.); zakr. rel. 11, k. 242 (1757 r.).

${ }^{24}$ Tylko pięć w czterech aktach z lat 1701-1759, AGAD, zakr. grodz. wiecz., 111, k. 130 (1711 r.); zakr. grodz. rel., 8, k. 727v (1701 r.); 42, k. 1v (1746 r.); 61, k. 677 (1759 r.).

${ }^{25}$ AGAD, zakr. grodz. rel., 47, k. 397 (1749 r.); 66, k. 712v (1771 r.).

${ }^{26}$ AGAD, zakr. grodz. rel., 5, k. 460v (1677 r.); zakr. grodz. wiecz., 111, k. 130 (1711 r.).

27 AGAD, zakr. grodz. rel., 5, k. 460v.

${ }_{28}$ AGAD, zakr. grodz. wiecz., 117, k. 278. 
go Koskowskiego z miejscowości Gumowo Płaszki ${ }^{29}$. Natomiast droższym wyrobem (wycenionym na 7 zł), chociaż już w złym stanie, był „kilimek, stary dziurawy”, należący do Wojciecha Borowskiego w $1790 \mathrm{r}^{30} \mathrm{~W}$ dwóch przypadkach zaznaczono jego umiejscowienie; wisiał nad łóżkiem u imć Krajewskiego, zmarłego w 1716 r. na komorze celnej w Zakroczymiu, oraz u cześnika nowogrodzkiego Stanisława Golimskiego w 1749 r. $^{31}$ (tab. 3). Dwukrotnie scharakteryzowano wyrób jako „czerwony turecki” (w latach 1713 i 1716) 32, a raz jako „,kilimek turecki stary podarty" u łowczego przasnyskiego Adama Łaźniewskiego $(1783 \text { r. })^{33}$. Z kolei sześć sztuk „ruskiej roboty” spisano w domu Felicjana Ołdakowskiego (w 1746 r.) ${ }^{34}$ (tab. 4).

Tabela 3

Liczba kilimów w analizowanych źródłach

Table 3

Number of kilims in the analysed sources

\begin{tabular}{|l|c|c|c|c|c|}
\hline \multicolumn{1}{|c|}{ Lata } & $\begin{array}{c}\text { Liczba przekazów } \\
\text { ogółem }\end{array}$ & $\begin{array}{c}\text { Liczba sztuk } \\
\text { kilimów }\end{array}$ & $\begin{array}{c}\text { Liczba } \\
\text { przekazów }\end{array}$ & $\begin{array}{c}\text { Procent } \\
\text { przekazów }\end{array}$ & Średnio \\
\hline $1651-1700$ & 29 & 16 & 10 & 34,48 & 1,60 \\
\hline $1701-1750$ & 71 & 23 & 11 & 15,49 & 2,09 \\
\hline $1751-1800$ & 59 & 14 & 10 & 16,95 & 1,40 \\
\hline Razem & 159 & 53 & 31 & 19,51 & 1,71 \\
\hline
\end{tabular}

Tabela 4.

Liczba dywanów w analizowanych źródłach

Table 4

Number of floor carpets in the analysed sources

\begin{tabular}{|l|c|c|c|c|c|}
\hline \multicolumn{1}{|c|}{ Lata } & $\begin{array}{c}\text { Liczba przekazów } \\
\text { ogółem }\end{array}$ & $\begin{array}{c}\text { Liczba sztuk } \\
\text { dywanów }\end{array}$ & $\begin{array}{c}\text { Liczba } \\
\text { przekazów }\end{array}$ & $\begin{array}{c}\text { Procent } \\
\text { przekazów }\end{array}$ & Średnio \\
\hline $1651-1700$ & 29 & 0 & 0 & 0,00 & 0,00 \\
\hline $1701-1750$ & 71 & 13 & 4 & 5,63 & 3,25 \\
\hline $1751-1800$ & 59 & 27 & 16 & 27,12 & 1,69 \\
\hline Razem & 164 & 40 & 20 & 12,20 & 2,00 \\
\hline
\end{tabular}

Dywany, odnotowywane tylko w osiemnastowiecznych przekazach, miały różne zastosowanie (tab. 4). Jedne $\mathrm{z}$ nich okrywały łóżka ${ }^{35}$, inne wisiały nad nimi na ścianach ${ }^{36}$ albo leżały na stołach $^{37}$. Tylko raz podano wartość takiej tkaniny. Na 6 tynfów wyceniono w 1760 r. „dywan,

${ }^{29}$ AGAD, zakr. rel., 9, k. 212.

${ }^{30}$ AGAD, zakr. grodz. rel., 87, k. 88-88.

31 AGAD, zakr. grodz. rel., 17, k. 298 (1716 r.); 47, k. 397 (1749 r.).

32 AGAD, zakr. grodz. rel., 15, k. 133 (1713 r.); 17, k. 298 (1716 r.).

${ }^{33}$ AGAD, zakr. grodz. rel., 79, k. 901 (1783 r.).

34 AGAD, zakr. grodz. rel., 42, k. 1v (1746 r.).

35 Tak określono sześć sztuk w pięciu przekazach: AGAD, zakr. grodz. rel., 62, k. 370v (1760 r.); 66, k. 701v (1768 r.); 66, k. 712v (1771 r.); 67, k. 100v (1764 r.); 81, k. 161v (1785 r.).

36 „Dywan wyszywany nad łóżkiem”, AGAD, zakr. grodz. rel., 66, k. 712v (1771 r.) oraz „dywan nad łóżko kosmaty", AGAD, zakr. grodz. rel., 66, k. 740v (1771 r.).

37 „Dywan na stół krzyżowa robota” miał major regimentu łanowego koronnego, Czesław Ignacy Łempicki (AGAD, zakr. grodz. rel., 66, k. 740v, 1771 r.), zas „dywan na stół środek nowy z sukna karmazynowego listwy 
stary z łóżka”, stanowiący własność Franciszka Mieszkowskiego ${ }^{38}$. Siedmiokrotnie użyto wobec nich określenia ,turecki”, z czego trzy takie dywany były własnością stolnika sanockiego Mateusza Guzkowskiego (w 1785 r. $)^{39}$. Niektóre z wyrobów orientalnych przetykane były złotą nicią ${ }^{40}$. Zastanawia wyjaśnienie zawarte w dwóch dokumentach: „dywan na łóżko alias koc” $(1764 \text { r. })^{41}$ oraz „dywan czyli koc kosmaty roboty przez połowę włosianny i wełniany stary” (1770 r. $)^{42}$. Wątpliwości budzi zapis w inwentarzu pośmiertnym stolnika nowogrodzkiego Franciszka Czaczkowskiego z 1726 r.: jeden „dywan alias kobierzec ze stołu stary”, a drugi „dywan alias obicie proste”43. Czyżby stosowane określenie nie szło w parze z przeznaczeniem i wymagało dopowiedzenia?

Do tej grupy wyrobów należą także makaty, które sporadycznie znajdowały się wśród spisywanych rzeczy, w tym jedna karmazynowa $(1751 \text { r. })^{44}$, zaś druga ,turecka ze złotem” — własność starosty starorypińskiego Józefa Ciszowskiego (1778 r. $)^{45}$.

Kobierce, jak się wydaje, były oznaką wyższego poziomu życia, skoro wśród 29 osób, które je miały, 16 to urzędnicy ziemscy lub wdowy po nich oraz oficer. Tylko niekiedy analizowane wnętrza ozdabiano dwoma rodzajami tkanych materii, tj. kobiercem i kilimem ${ }^{46}$, kobiercem i dywanem ${ }^{47}$, bądź kilimem i dywanem ${ }^{48}$.

W wielu siedzibach w użytkowaniu były takie przedmioty jak płotki, pawilony, parawany, kotary i zasłony. Niekiedy precyzowano ich zastosowanie — „do łóżka” lub „na łóżko”, co sugeruje ich przeznaczenie do wydzielania przestrzeni wokół miejsca na sen, do budowania

w kwiaty białe wyrabiane" Apolonia Strzałkowska z Fredrów, wdowa po Aleksandrze, chorążym zakroczymskim (AGAD, zakr. grodz. rel., 36, k. 235a, 1741 r.). Natomiast „dywan na stół turecki na białym lnie” należał do stolnika sanockiego Mateusza Guzkowskiego (AGAD, zakr. grodz. rel., 82, k. 593, 1785 r.).

38 AGAD, zakr. grodz. rel., 62, k. 370v (1760 r.).

${ }^{39}$ AGAD, zakr. grodz. rel., 44, k. 59 (1751 r.); 61, k. 677 (1759 r.); 66, k. 701v (1768 r.); 82, k. 593 (1785 r.).

40 Tak należy rozumieć opisy: „turecki niewielki ze złotem”, należący do Apolonii Strzałkowskiej (AGAD, zakr. grodz. rel., 36, k. 235a, 1741 r.), „turecki złoty” (AGAD, zakr. grodz. rel., 44, k. 59, 1751 r.), ,zielony tureckiej roboty ze złotem", będący własnością Jakuba Jaroszewskiego (AGAD, zakr. grodz. rel., 61, k. 677, 1759 r.).

${ }^{41}$ AGAD, zakr. grodz. rel., 67, k. 100v (1764 r.).

42 AGAD, zakr. grodz. rel., 66, k. 631 (1770 r.).

${ }^{43}$ AGAD, zakr. grodz. rel., 25, k. 144c (1726 r.).

44 AGAD, zakr. grodz. rel., 44, k. 59 (1751 r.).

45 AGAD, zakr. grodz. rel., 78, k. 66 (1778 r.).

46 Było tak w ośmiu domach, należących do: wojskiego zakroczymskiego Jacka Lasockiego — 4 kobierce i 2 kilimy (AGAD, zakr. grodz. wiecz., 81, k. 395, 1677 r.), Heleny Oborskiej, wdowy po Wojciechu DuninMiączyńskim — po jednym (AGAD, zakr. grodz. wiecz., 107, k. 166v-167, 1691 r.), Marianny z Wielowieyskich Ciszkowskiej, wdowy po Franciszku — po jednym (AGAD, zakr. grodz. wiecz., 108, k. 568v, 1698 r.), Jana Górskiego - 4 kobierce i 2 kilimy (AGAD, zakr. grodz. rel., 8, k. 270, 1699 r.), do Anny Latynowej z Lubeckich — kobierzec i dwa klimy (AGAD, zakr. grodz. wiecz., 117, k. 278, 1743 r.), Felicjana Ołdakowskiego — 2 kobierce i 6 kilimów (AGAD, zakr. grodz. rel., 42, k. 1v, 1746 r.), cześnika nowogrodzkiego Stanisława Golimskiego — po jednym (AGAD, zakr. grodz. rel., 47, k. 397, 1749 r.), cześnika zakroczymskiego Jakuba Prusinowskiego - także po jednym (AGAD, zakr. grodz. rel., 8, k. 232, 1699 r.).

472 kobierce i 1 dywan odnotowano u podczaszego winnickiego Franciszka Wittana (AGAD, zakr. grodz. rel., 22, k. 43-43v), 8 dywanów i 6 kobierców u wdowy Strzałkowskiej, chorążyny zakroczymskiej (AGAD, zakr. grodz. rel., 36, k. 235a, 1741 r.), 3 dywany i 2 kobierce u nieznanego z imienia i nazwiska szlachcica (AGAD, zakr. grodz. rel., 44, k. 58, 1751 r.), 2 dywany i kobierzec u cześnika nowogrodzkiego Stanisława Golimskiego (AGAD, zakr. grodz. rel., 47, k. 397, 1749 r.), 1 dywan i 2 kobierce u chorążego zakroczymskiego Jakuba Jaroszewskiego (AGAD, zakr. grodz. rel., 61, k. 676v, 1759 r.), 4 dywany i 2 kobierce u starościca mścisławskiego Krzysztofa Wołłowicza (AGAD, zakr. grodz. rel., 66, k. 712v, 1771 r.).

${ }_{48}$ Spisano: po jednym u Franciszka Mieszkowskiego (AGAD, zakr. grodz. rel., 62, k. 370v, 1760 r.) oraz Macieja Dramińskiego (AGAD, zakr. grodz. rel., 82, k. 361v, 1785 r.), 4 dywany i 1 kilim u stolnika nowogrodzkiego Franciszka Czaczkowskiego (AGAD, zakr. grodz. rel., 25, k. 144c, 1726 r.), 2 dywany i 1 kilim u cześnika nowogrodzkiego Stanisława Golimskiego (AGAD, zakr. grodz. rel., 47, k. 397, 1749 r.), po jednym u łowczego przasnyskiego Adama Łaźniewskiego (AGAD, zakr. grodz. rel., 79, k. 901, 1783 r.), po dwa klimy i dywany u komornika granicznego zakroczymskiego, Jacka Sobolewskiego (AGAD, zakr. grodz. rel., 73, k. 129, 1775 r.). 
nastroju intymności. Co ciekawe, tylko w jednym domu — Piotra Maruszewskiego w 1785 r. — odnotowano zarówno dwa pawilony (kitajkowy żółty oraz bagazjowy zły), jak i parawan (czerwony $)^{49}$. W pozostałych wnętrzach występowały pojedynczo albo, jak się zdaje, miały odmienną wielkość — parawany mniejsze albo większe, co sugeruje sformułowanie „na wielkie łóżko" 50 . Znana jest cena jednego z nich. W 1795 r. odnotowano „kitajkowy karmazynowy nowy kosztujący zł 100”51. Wyjątkowo do innego celu służył „parawanik kitajkowy zielony do kuminka zł 18" "52. Do nich wykonania używano przede wszystkim jedwabnej kitajki, adamaszku i atłasu oraz płótna i bagazji, a także wełnianej rasy (arrasu) ${ }^{53}$. Niekiedy pawilony i kotary zdobiono srebrnym lub złotym galonem ${ }^{54}$.

Niezbędnym sprzętem do oświetlania wnętrz były lichtarze. Ich frekwencja w poszczególnych przekazach pośrednio może wskazywać na wielkość domów i liczbę znajdujących się w nich pomieszczeń. Najwięcej, bo 24, miał ich starosta starorypiński Józef Ciszowski (w 1778 r. $)^{55}$. Po kilkanaście wchodziło w skład wyposażenia dworów: Franciszka Czaczkowskiego (13 sztuk, w 1726 r.) i Czesława Łempickiego (12, w 1771 r. $)^{56}$. Niemal połowę z nich wykonano z cyny, a co czwarty ze srebra, przy czym te ostatnie odnotowano zaledwie w siedmiu $\operatorname{spisach}^{57}$ (tab. 5).

Tabela 5.

Liczba lichtarzy w analizowanych źródłach

Table 5.

Number of candlesticks in the analysed sources

\begin{tabular}{|l|c|c|c|c|c|}
\hline \multicolumn{1}{|c|}{ Lata } & $\begin{array}{c}\text { Liczba przekazów } \\
\text { ogółem }\end{array}$ & $\begin{array}{c}\text { Liczba sztuk } \\
\text { lichtarzy }\end{array}$ & $\begin{array}{c}\text { Liczba } \\
\text { przekazów }\end{array}$ & $\begin{array}{c}\text { Procent } \\
\text { przekazów }\end{array}$ & Średnio \\
\hline $1651-1700$ & 29 & 14 & 8 & 27,59 & 1,75 \\
\hline $1701-1750$ & 71 & 65 & 16 & 22,54 & 4,06 \\
\hline $1751-1800$ & 59 & 102 & 21 & 35,59 & 4,86 \\
\hline Razem & 164 & 181 & 45 & 27,44 & 4,02 \\
\hline
\end{tabular}

49 AGAD, zakr. grodz. rel., 81, k. 160v i 166.

${ }^{50}$ AGAD, zakr. grodz. rel., 8, k. 727v (1701 r.); 65, k. 60 (1759 r.).

51 AGAD, zakr. ziem. wiecz. rel., 112, k. 185.

52 AGAD, zakr. ziem. wiecz. rel., 112, k. 252v (1795 r.).

${ }^{53}$ Z kitajki - 18 przedmiotów (AGAD, zakr. grodz. rel., 8, k. 727v, 1701 r.; 17, k. 92, 1715 r.; 36, k. 235a, 1741 r. dwukrotnie; 52, k. 435v, 1748 r.; 50, k. 224v, 1750 r. dwukrotnie; 54, k. 151, 1754 r.; 61, k. 676v, 1759 r.; 66, k. 701v, 1768 r. dwukrotnie; 66, k. 740v, 1771 r.; 66, k. 763, 1772 r.; 79, k. 901v, 1783 r.; 81, k. 160v, 1785 r. dwukrotnie; AGAD, zakr. ziem. wiecz. rel., 112, k. 185, 1795 r.; 112, k. 252v, 1795 r.; AGAD, zakr. grodz. wiecz., 117, k. 276v, 1743 r.); z płótna — 8 wyrobów (AGAD, zakr. grodz. rel., 46, k. 96v, 1750 r.; 66, k. 699, 1769 r.; 66 , k. 741, 1771 r.; 67, k. 238, 1765 r.; 82, k. 593v, 1785 r.; AGAD, zakr. ziem. wiecz. rel., 112, k. 252v, 1795 r.; 114 , k. 129v, 1791 r.); z bagazji - 2 parawany (AGAD, zakr. grodz. rel., 60, k. 805, 1759 r.; 81, k. 160v, 1785 r.); z rasy - 3 przedmioty (AGAD, zakr. grodz. rel., 20, k. 213v, 1721 r.; 46, k. 97v, 1750 r.; AGAD, zakr. rel., 11, k. 242v, 1757 r.). Charakterystyczne jest, że tkaniny jedwabne w kolorze karmazynowym mieli szlachcice piastujący urzędy, np. ,kotara, adamaszkowa z kołdrą na pojedyncze łóżko karmazynowa” u Józefa Ciszowskiego (AGAD, zakr. grodz. rel., 78, k. 66, 1778 r.), ,zasłony, w łóżku karmazynowe materiał atłasowy z poduszkami 2 takimi samymi” u Krzysztofa Koryckiego (AGAD, zakr. grodz. rel., 5, k. 460v, 1677 r.) oraz o takich tradycjach: „u stolnikowicza Wiktora Zielinskiego pawilon adamaszkowy karmazynowy" (AGAD, zakr. grodz. rel., 76, k. 744v, 1780 r.).

54 AGAD, zakr. grodz. rel., 36, k. 235a (1741 r.); 54, k. 151 (1754 r.); AGAD, zakr. grodz. wiecz., 117, k. 276v (1743 r.).

55 Miał 6 cynowych lichtarzy i 18 srebrnych, AGAD, zakr. grodz. rel., 78, k. 64v-66 (1778 r.).

56 AGAD, zakr. grodz. rel., 25, k. 144a (1726 r.); 66, k. 739v (1771 r.).

57 W analizowanych źródłach spisano 91 lichtarzy z cyny, 47 ze srebra, 23 z mosiądzu, 5 z princmetalu oraz po 1 z blachy, drutu i miedzi. Srebrne, najlepiej świadczące o zamożności domu, mieli: Helena z Sufczyńskich 
Kolejny mebel, nieodzowny w pomieszczeniach budynku mieszkalnego, to stół. Tymczasem wzmiankowano go jedynie w co trzecim analizowanym dokumencie; średnio po dwa w jednej siedzibie (tab. 6). Najwięcej stołów i stolików (po 7) stało u stolnika sanockiego Mateusza Guzkowskiego (1785 r. $)^{58}$ i Piotra Maruszewskiego. Ten ostatni miał okazały egzemplarz — „stolik, malowany po brzegach wyzłacany” (1785 r.), co wskazuje na podążanie za ówczesną modą w meblarstwie ${ }^{59}$. Opisując te sprzęty, zwracano raczej uwagę na ich wielkość, rzadziej na inne cechy. $\mathrm{Z}$ informacji o gatunku drzewa, z którego zostały one wykonane, wynika, że używano do tego celu drewna sosnowego, dębowego lub jesionowego ${ }^{60}$. Niektóre stoły zaopatrzone były w szuflady ${ }^{61}$. W drugiej połowie XVIII w. w użyciu były też stoły wyróżniające się okrągłym kształtem ${ }^{62}$ lub konstrukcją umożliwiającą ich rozłożenie ${ }^{63}$.

Tabela 6.

Liczba stołów i stolików w analizowanych źródłach

Table 6.

Number of tables and small tables in the analysed sources

\begin{tabular}{|l|c|c|c|c|c|}
\hline \multicolumn{1}{|c|}{ Lata } & $\begin{array}{c}\text { Liczba przekazów } \\
\text { ogółem }\end{array}$ & $\begin{array}{c}\text { Liczba sztuk } \\
\text { stołów i stolików }\end{array}$ & $\begin{array}{c}\text { Liczba } \\
\text { przekazów }\end{array}$ & $\begin{array}{c}\text { Procent } \\
\text { przekazów }\end{array}$ & Średnio \\
\hline $1651-1700$ & 29 & 7 & 2 & 6,90 & 0,00 \\
\hline $1701-1750$ & 71 & 39 & 27 & 38,03 & 1,44 \\
\hline $1751-1800$ & 59 & 61 & 21 & 35,59 & 2,90 \\
\hline Razem & 164 & 107 & 50 & 30,49 & 2,14 \\
\hline
\end{tabular}

Karczewska - parę (AGAD, zakr. grodz. rel., 54, k. 151, 1754 r.), Jan Bakałowicz - 7 sztuk (AGAD, zakr. ziem. wiecz. rel., 112, k. 251, 1795 r.), Franciszek Wittan, podczaszy winnicki — parę (AGAD, zakr. grodz. rel., 22, k. 43, 1722 r.), Franciszek Czaczkowski - tuzin takich wyrobów (AGAD, zakr. grodz. rel., 25, k. 144a, 1726 r.), Apolonia z Fredrów Strzałkowska - 4 (AGAD, zakr. grodz. rel., 36, k. 235v, 1741 r.), Jakub Jaroszewski, chorąży zakroczymski — parę (AGAD, zakr. grodz. rel., 61, k. 677v, 1759 r.), zaś Józef Ciszowski — 18 (AGAD, zakr. grodz. rel., 78, k. 65, 1778 r.).

58 AGAD, zakr. grodz. rel., 82, k. 594 (1785 r.).

59 AGAD, zakr. grodz. rel., 81, k. 165v (1785 r.).

${ }^{60}$ Pięciokrotnie użyto określenia ,sosnowy”: trzy takie stoły miał Jakub Jaroszewski (AGAD, zakr. grodz. rel., 61, k. 677, 1759 r.), po jednym Czesław Ignacy Łempicki (AGAD, zakr. grodz. rel., 66, k. 741, 1771 r.) oraz Piotr Maruszewski (AGAD, zakr. grodz. rel., 81, k. 165v, 1785 r.). Czterokrotnie wspomniano „dębowy” mebel, który należał do wspomnianych wyżej Jaroszewskiego i Łempickiego (po jednym), a także do Marianny z Kozłowskich Jakackiej, żony Wiktora Stanisława (AGAD, zakr. grodz. rel., 81, k. 138, 1788 r.) i do stolnika sanockiego Mateusza Guzkowskiego (AGAD, zakr. grodz. rel., 82, k. 594, 1785 r.). „Stolik mały jesionowy z szufladką" miał tylko Łempicki (AGAD, zakr. grodz. rel., 66, k. 741, 1771 r.).

${ }^{61} \mathrm{~W}$ ten sposób zrobionych było 16 stołów i stolików, AGAD, zakr. grodz. rel., 14, k. 161v (1714 r.); 42 , k. 2 (1746 r.); 47, k. 397v (1749 r. dwukrotnie); 62, k. 80 (1760 r.); 65, k. 60 (1759 r.); 66, k. 713 (1771 r.); 66 , k. 741 (1771 r. dwukrotnie); 73, k. 127v (1775 r.); 81, k. 165v (1785 r.); 82, k. 361v (1785 r.); 11, k. 242v (1757 r.); AGAD, zakr. ziem. wiecz. rel., 109, k. 516 (1776 r.).

${ }^{62}$ Dwa takie sprzęty miał podwojewodzic warszawski Kasper Dybowski (AGAD, zakr. grodz. rel., 52, k. 506v, 1753 r.) oraz chorąży zakroczymski Jakub Jaroszewski (AGAD, zakr. grodz. rel., 61, k. 677, 1759 r.). Jeden stół okrągły był własnością: Piotra Maruszewskiego (AGAD, zakr. grodz. rel., 81, k. 165v, 1785 r.), stolnika sanockiego Mateusza Guzkowskiego (AGAD, zakr. grodz. rel., 82, k. 594v, 1785 r.) i komornika granicznego zakroczymskiego, Jacka Sobolewskiego (AGAD, zakr. grodz. rel., 73, k. 127v, 1775 r.). Wyróżniał się niewątpliwie sprzęt Jaroszewskiego, opisany następująco: „stolik dębowy w środku marmur czarny potłuczony na nóżkach okrągłych toczony" (AGAD, zakr. grodz. rel., 61, k. 677, 1759 r.). Prawdopodobnie podobny mebel — „stolik dębowy, w którym marmur czarny śrzodkiem” stał w 1722 r. w alkierzyku dworku w Oblęgorze Większym, w powiecie chęcińskim (Pielas J. 2018, s. 65).

63 „Stolik, składany suknem zielonym wybity” miał łowczy przasnyski Adam Łaźniewski, AGAD, zakr. grodz. rel., 79, k. 900v (1783 r.). 
Tabela 7.

Liczba stołków w analizowanych źródłach

Table 7.

Number of stools in the analysed sources

\begin{tabular}{|l|c|c|c|c|c|}
\hline \multicolumn{1}{|c|}{ Lata } & $\begin{array}{c}\text { Liczba przekazów } \\
\text { ogółem }\end{array}$ & $\begin{array}{c}\text { Liczba sztuk } \\
\text { stołków }\end{array}$ & $\begin{array}{c}\text { Liczba } \\
\text { przekazów }\end{array}$ & $\begin{array}{c}\text { Procent } \\
\text { przekazów }\end{array}$ & Średnio \\
\hline $1651-1700$ & 29 & 8 & 1 & 3,45 & 8,00 \\
\hline $1701-1750$ & 71 & 35 & 5 & 7,04 & 7,00 \\
\hline $1751-1800$ & 59 & 27 & 16 & 27,12 & 8,63 \\
\hline Razem & 164 & 181 & 22 & 13,41 & 8,23 \\
\hline
\end{tabular}

Najczęściej odnotowywanym meblem do siedzenia były drewniane, okrągłe lub prostokątne stołki (tab. 7). By poprawić komfort ich użytkowania oraz nadać im bardziej dekoracyjny wygląd, niekiedy miały poręcze ${ }^{64}$ lub były obite tkaninami ${ }^{65}$. Najczęściej było ich kilka w jednej siedzibie. Wyjątkowo dużo (aż 30 sztuk) miał w swoim domu starościc mścisławski Krzysztof Wołłowicz $(1771 \mathrm{r} \text {. })^{66}$. Rzadziej w uwzględnionych przekazach rejestrowano inne sprzęty o analogicznej funkcji: zydle ${ }^{67}$, taborety ${ }^{68}$ bądź ławy ${ }^{69}$ (tab. 8).

Tabela 8 .

Liczba krzeseł w analizowanych źródłach

Table 8 .

Number of chairs in the analysed sources

\begin{tabular}{|l|c|c|c|c|c|}
\hline \multicolumn{1}{|c|}{ Lata } & $\begin{array}{c}\text { Liczba przekazów } \\
\text { ogółem }\end{array}$ & $\begin{array}{c}\text { Liczba sztuk } \\
\text { krzeseł }\end{array}$ & $\begin{array}{c}\text { Liczba } \\
\text { przekazów }\end{array}$ & $\begin{array}{c}\text { Procent } \\
\text { przekazów }\end{array}$ & Średnio \\
\hline $1651-1700$ & 29 & 0 & 0 & 0,00 & 0,00 \\
\hline $1701-1750$ & 71 & 13 & 4 & 5,63 & 3,25 \\
\hline $1751-1800$ & 59 & 29 & 16 & 27,12 & 1,69 \\
\hline Razem & 164 & 40 & 20 & 12,20 & 2,00 \\
\hline
\end{tabular}

${ }^{64}$ Takie stołki mieli: Felicjan Ołdakowski - 10 sztuk (AGAD, zakr. grodz. rel., 42, k. 2v, 1746 r.), kapitan gwardii królewskiej Antoni Osiecki - 2 sztuki (AGAD, zakr. grodz. rel., 46, k. 98, 1750 r.), cześnik nowogrodzki Stanisław Golimski - nieznaną liczbę (AGAD, zakr. grodz. rel., 47, k. 397v, 1749 r.), sędzia kapturowy różański Kazimierz Budzyński - 4 sztuki (AGAD, zakr. grodz. rel., 67, k. 100v, 1764 r.).

656 stołków obitych tryprą w kolorze błękitnym znajdowało się w domu majora regimentu łanowego koronnego, Czesława Ignacego Łempickiego (AGAD, zakr. grodz. rel., 66, k. 741, 1771 r.), a dwa opisane jako „małe obite materią starą bardzo złe" w Smolsku, u Antoniego Drozdowskiego (AGAD, zakr. rel., 11, k. 242v, 1757 r.).

${ }^{66}$ AGAD, zakr. grodz. rel., 66, k. 712v (1771 r.).

${ }^{67}$ Jeden zydel „,z poręczami” wymieniono u komornika ziemi zakroczymskiej Mateusza Śniadowskiego (AGAD, zakr. grodz. rel., 84, k. 167v, 1787 r.), natomiast 15 sztuk, z czego 13 „z poręczami”, u komornika granicznego zakroczymskiego Jacka Sobolewskiego (AGAD, zakr. grodz. rel., 73, k. 127v, 1775 r.) oraz 4 u Mikołaja Łady (AGAD, zakr. grodz. rel., 52, k. 471v, 1751 r.).

68 Taborety opisano następujaco: ,para krzyżowa robota”, u Salomei z Jaroszewskich Januszewskiej (AGAD, zakr. grodz. rel., 52, k. 435v, 1748 r.), ,zielonym suknem obite 2” u podwojewodzica warszawskiego Kaspra Dybowskiego (AGAD, zakr. grodz. rel., 52, k. 506v, 1753 r.), jeden „włóczką szyty” u chorążego zakroczymskiego Jakuba Jaroszewskiego (AGAD, zakr. grodz. rel., 61, k. 677, 1759 r.) i jeden „,suknem obity” u łowczego przasnyskiego Adama Łaźniewskiego (AGAD, zakr. grodz. rel., 79, k. 903v, 1783 r.).

${ }^{69}$ Tylko w pierwszej połowie XVIII w. w trzech przekazach wspomniano o ławach stojących ,w izbie stołowej” (AGAD, zakr. grodz. rel., 21, k. 98, 1718 r.), „,koło stołu” w domu Franciszka Lasockiego (AGAD, 
W badanym okresie w domach szlachty zakroczymskiej, jak można sądzić, krzesła nie były jeszcze powszechnym sprzętem. Wzmiankowano je w co jedenastym przekazie. W pierwszej połowie XVIII w. było ich po kilka. Dopiero w źródłach powstałych począwszy od lat sześćdziesiątych tegoż stulecia wymieniano ich więcej, np. sześć krzeseł „skórą obitych" u komornika ziemskiego różańskiego Mateusza Tańskiego (1765 r. $)^{70}$ lub tuzin bliżej nieopisanych, należących do starosty starorypińskiego Józefa Ciszowskiego (1778 r.) $)^{71}$. Zgodnie z ówczesną modą krzesła obijano skórą ${ }^{72}$ lub tkaninami ${ }^{73}$, o czym niekiedy nadmieniano. Prawdopodobnie do wieku i do wzrostu dzieci dostosowane były te, które opisano jako „dla dzieci połamane złe"74 oraz „dziecinne" 75 . Przypuszczalnie wyrazem znacznych możliwości materialnych i wysokich aspiracji społecznych stolnika sanockiego Mateusza Guzkowskiego (dokument z 1785 r.) był „garnitur” złożony z kanap i krzeseł, ozdobionych tym samym materiałem. Dwie kanapy „trypą karmazynową” obite tworzyły komplet z 18 krzesłami, zaś inna, opisana jako „gdańska żółtym płótnem wybita”, z tuzinem takich mebli siedziskowych ${ }^{76}$. Po jednej kanapie mieli zaś major regimentu łanowego koronnego, Czesław Ignacy Łempicki (1771 r.), starosta starorypiński Józef Ciszowski (1778 r.) oraz Jan Bakałowicz (1795 r.) $)^{77}$.

Tabela 9.

Liczba skrzyń w analizowanych źródłach

Table 9.

Number of chests in the analysed sources

\begin{tabular}{|l|c|c|c|c|c|}
\hline \multicolumn{1}{|c|}{ Lata } & $\begin{array}{c}\text { Liczba przekazów } \\
\text { ogółem }\end{array}$ & $\begin{array}{c}\text { Liczba sztuk } \\
\text { skrzyń }\end{array}$ & $\begin{array}{c}\text { Liczba } \\
\text { przekazów }\end{array}$ & $\begin{array}{c}\text { Procent } \\
\text { przekazów }\end{array}$ & Średnio \\
\hline $1651-1700$ & 29 & 16 & 9 & 31,03 & 1,78 \\
\hline $1701-1750$ & 71 & 68 & 29 & 40,85 & 2,34 \\
\hline $1751-1800$ & 59 & 63 & 29 & 49,15 & 2,17 \\
\hline Razem & 164 & 147 & 67 & 40,85 & 2,19 \\
\hline
\end{tabular}

Do przechowywania rozmaitych rzeczy służyły skrzynie (tab. 9), najbardziej rozpowszechnione w badanych domostwach, zróżnicowane pod względem przeznaczenia, wielkości i kolo-

zakr. grodz. rel., 8, k. 866v, 1706 r.), oraz „około stołu tokarska robota”, należących do wojskiego zakroczymskiego Franciszka Zaborowskiego (AGAD, zakr. grodz. rel., 38, k. 118, 1742 r.).

${ }^{70}$ AGAD, zakr. grodz. rel., 67, k. 238v (1765 r.).

71 AGAD, zakr. grodz. rel., 78, k. 66v (1778 r.).

72 Oprócz wspomnianych 6 krzeseł u Tańskiego (AGAD, zakr. grodz. rel., 21, k. 98, 1718 r.), takie sprzęty obijane skórą odnotowano również: u Wojciecha Szygowskiego - 4 sztuki (AGAD, zakr. grodz. rel., 11, k. 314v, 1708 r.), u Apolonii, wdowy po Aleksandrze Strzałkowskim — nieokreśloną liczbę krzeseł obijanych w Gdańsku (AGAD, zakr. grodz. rel., 36, k. 235cv, 1741 r.), u Antoniego Osieckiego, kapitana gwardii królewskiej - 3 (AGAD, zakr. grodz. rel., 46, k. 97v, 1750 r.), u łowczego przasnyskiego Adama Łaźniewskiego — 6 (AGAD, zakr. grodz. rel., 79, k. 903v, 1783 r.). W domach gdańszczan w XVIII w. także ustawiano w izbach po sześć lub 12 krzeseł (Barylewska-Szymańska E. 2015, s. 111).

73 Dwa krzesła „suknem karmazynowym obite stare” figurowały w inwentarzu pośmiertnym chorążego zakroczymskiego Jakuba Jaroszewskiego, AGAD, zakr. grodz. rel., 61, k. 677 (1759 r.).

${ }^{74}$ AGAD, zakr. ziem. wiecz. rel., 105, k. 335 (1743 r.).

75 AGAD, zakr. grodz. rel., 81, k. 166v (1785 r.).

${ }^{76}$ AGAD, zakr. grodz. rel., 82, k. 593v (1785 r.).

77 Kanapy: „olszowa z przykryciem cycowym” (AGAD, zakr. grodz. rel., 66, k. 741, 1771 r.), bliżej nieopisana (AGAD, zakr. grodz. rel., 78, k. 66v, 1778 r.) oraz „bez pokrowców [o wartości — D.G.] zł 36” (AGAD, zakr. ziem. wiecz. rel., 112, k. 252v, 1795 r.). 


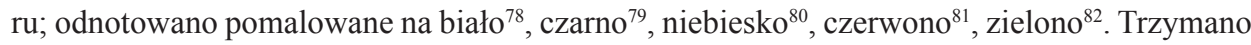

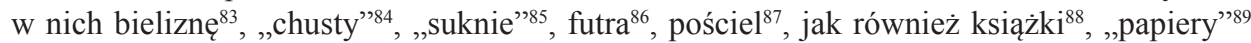
$\mathrm{i}$ „,korzenie" ${ }^{90}$. Niektóre z nich miały konstrukcję wzmocnioną metalowymi elementami (,okowane") ${ }^{91}$, albo ścianki obite skórą 92 . W uwzględnionych źródłach nie wspomniano o skrzyniach ozdabianych herbem, które znane są z osiemnastowiecznej Wielkopolski ${ }^{33}$.

Szafę w analizowanych dokumentach wzmiankowano po raz pierwszy w roku $1700^{94}$. W następnych latach coraz częściej figurowała wśród spisanego dobytku, lecz nie stała się meblem powszechnie spotykanym. W domach, w których zdecydowano się na jej postawienie, odnotowywano ją obok skrzyń. Chociaż poszerzyła się przestrzeń do przechowywania rzeczy, to nie nastąpiła wymiana starego typu mebla na nowy. Wygląd i funkcje szaf najpełniej opisano w inwentarzu pośmiertnym wdowy po Aleksandrze Strzałkowskim, chorążym zakroczymskim z $1741 \mathrm{r}$. W akcie zanotowano kilka tego typu mebli wraz z informacjami dotyczącymi ich budowy i zawartości: szafka „ze stolikiem z wierzchu się otwierająca w której książki różne”, szafa „z dwoma przegrodami i kratkami, szkło a na dole noże, lichtarze”, szafka „okrągła od dołu zamknięcie a wyżej 3 przegrody[,] gdzie imbryki, filiżanki i inne”, oraz kolejna szafa ,z szufladami i przegrodami, w której różne są flasze, słoiczki od olejków i lekarstwa"95. Warto też zwrócić uwagę na mebel określony jako „szafka duża w orzech malowana”, zarejestrowany w 1750 r. u Antoniego Osieckiego $^{96}$. Takie sprzęty fornirowane drewnem orzechowym używane były w domach gdańszczan w drugiej połowie XVIII w. ${ }^{97}$ (tab. 10). W 1759 r. w inwentarzu pośmiertnym chorążego zakroczymskiego Jakuba Jaroszewskiego, spośród sześciu szaf ze względu na opis warto wskazać trzy:

${ }^{78}$ AGAD, zakr. grodz. wiecz., 106, k. 134v (1681 r.); AGAD, zakr. grodz. rel., 8, k. 727 (1701 r.); k. 816 (1705 r.).

${ }^{79}$ AGAD, zakr. grodz. rel., 8, k. 727 (1701 r.).

${ }^{80}$ AGAD, zakr. grodz. rel., 81, k. 166 (1785 r.).

${ }^{81}$ AGAD, zakr. grodz. rel., 36, k. 235a (1741 r.).

${ }^{82}$ AGAD, zakr. grodz. wiecz., 106, k. 134v (1681 r.); AGAD, zakr. grodz. rel., 47, k. 397v (1749 r.); 61 , k. 677v (1759 r.); 81, k. 138 (1788 r.).

${ }^{83}$ AGAD, zakr. grodz. rel., 46, k. 97v (1750 r.).

${ }^{84}$ AGAD, zakr. grodz. rel., 8, k. 727 (1701 r.); 61, k. 677 (1759 r.).

${ }^{85}$ AGAD, zakr. grodz. rel., 36, k. 235av (1741 r.).

${ }^{86}$ AGAD, zakr. grodz. rel., 36, k. k. 235b (1741 r.).

${ }^{87}$ AGAD, zakr. grodz. rel., 36, k. 235b (1741 r.); 54, k. 45v (1754 r.); 66, k. 713 (1771 r.); 79, k. 900v (1783 r.); 82, k. 361v (1785 r.); 84, k. 166 (1787 r.); AGAD, zakr. ziem. wiecz. rel., 105, k. 335 (1743 r.); 112 , k. $173 \mathrm{v}(1795 \mathrm{r}$.).

${ }^{88}$ AGAD, zakr. grodz. rel., 44, k. 58 (1751 r.).

89 AGAD, zakr. grodz. wiecz., 81, k. 395 (1677 r.); AGAD, zakr. grodz. rel., 25, k. 144d (1726 r.); 47, k. 397v (1749 r.); 54, k. 78v (1754 r.); 81, k. 165v (1785 r.); AGAD, zakr. ziem. wiecz. rel., 109, k. 516 (1776 r.).

${ }^{90}$ AGAD, zakr. grodz. rel., 79, k. 901 (1783 r.).

${ }^{91}$ AGAD, zakr. grodz. wiecz., 81, k. 395 (1677 r.); AGAD, zakr. ziem. wiecz. rel., 105, k. 306 (1738 r.); AGAD, zakr. grodz. rel., 8, k. 816 (1705 r.); 15, k. 133 (1713 r.); 36, k. 235bv (1741 r.); 42, k. 2 (1746 r.); 47 , k. 397v (1749 r.); 50, k. 224v (1750 r.); 62, k. 370v (1760 r.); 65, k. 60 (1759 r.); 66, k. 713 (1771 r.); 73, k. 510 (1775 r.).

92 AGAD, zakr. grodz. rel., 36, k. 235av i 235 b (1741 r.); 46, k. 97v (1750 r.).

93 Dumanowski J. 2006, s. 53-55.

$94 \mathrm{~W}$ inwentarzu pośmiertnym stolnika czernichowskiego Franciszka Zaleskiego, AGAD, zakr. grodz. rel., 8, k. 316v.

95 AGAD, zakr. grodz. rel., 36, k. 235c-235 cv.

${ }_{96}$ AGAD, zakr. grodz. rel., 46, k. 97v.

${ }^{97}$ Bardzo rzadko określano miejsce ustawienia danego mebla, tym bardziej interesujacy jest zapis o innej „szafce z kratą w sieni”, AGAD, zakr. grodz. rel., 46, k. 97v (1750 r.); por.: Barylewska-Szymańska E. 2015, s. 74 i n., 109. 
„,do kredensu sosnowa u dołu zamykana”, „, do wieszania sukien dębowa wielka”, ,,sosnowa malowana w orzech z szufladkami’"98. Niewątpliwie nowym rodzajem szafek w drugiej połowie XVIII w. były: „,rogówka mała" ${ }^{99}$ oraz „kątowa stara"100.

Tabela 10 .

Liczba szaf w analizowanych źródłach

Table 10 .

Number of wardrobes in the analysed sources

\begin{tabular}{|l|c|c|c|c|c|}
\hline \multicolumn{1}{|c|}{ Lata } & $\begin{array}{c}\text { Liczba przekazów } \\
\text { ogółem }\end{array}$ & $\begin{array}{c}\text { Liczba sztuk } \\
\text { szaf }\end{array}$ & $\begin{array}{c}\text { Liczba } \\
\text { przekazów }\end{array}$ & $\begin{array}{c}\text { Procent } \\
\text { przekazów }\end{array}$ & Średnio \\
\hline $1651-1700$ & 29 & 1 & 1 & 3,45 & 1,00 \\
\hline $1701-1750$ & 71 & 26 & 13 & 18,31 & 2,00 \\
\hline $1751-1800$ & 59 & 43 & 23 & 38,98 & 1,87 \\
\hline Razem & 164 & 70 & 37 & 22,56 & 1,89 \\
\hline
\end{tabular}

Wolno zdobywały uznanie inne nowinki meblarskie — kredens i komoda. Spośród odnotowanych, pierwszy kredens stał w 1746 r. w siedzibie Felicjana Ołdakowskiego ${ }^{101}$. To jednak odosobniony przypadek w tym czasie. Dopiero po roku 1765 pojawiły się one w kilku domach: Franciszka Miecznikowskiego, starościca mścisławskiego Krzysztofa Wołłowicza, majora regimentu łanowego koronnego Czesława Ignacego Łempickiego, komornika ziemskiego różańskiego Mateusza Tańskiego, łowczego przasnyskiego Adama Łaźniewskiego i Piotra Maruszewskiego (po jednym egzemplarzu), a także u komornika granicznego zakroczymskiego, Jacka Sobolewskiego (dwie sztuki) ${ }^{102}$. Jedyna w zgromadzonych przekazach, bliżej nieopisana komoda, należała w 1785 r. do stolnika sanockiego Mateusza Guzkowskiego ${ }^{103}$.

Ubrania trzymano też w kufrach, których zastosowanie precyzuje określenie „od sukien”104. Raz wspomniano o wielkim kufrze, „w którym pościel” ${ }^{105}$. Z niektórych kufrów, jak również z sepetów, korzystano też w podróży ${ }^{106}$, przewożąc w nich potrzebne rzeczy (tab. 11, 12).

Kolejnym wyspecjalizowanym meblem był kantorek. Pod nazwą tą kryła się sekretera albo sekretarzyk, stanowiące rzadkość w badanych siedzibach. Stały w domach kilku osób piastujących urzędy lub — jak się wydaje — zamożnych. Wyróżniały się wysokim poziomem wykonania, użytym surowcem (dąb, jesion, orzech) i zdobnictwem ${ }^{107}$. Poza pełnieniem funkcji

98 AGAD, zakr. grodz. rel., 61, k. 677.

99 Należała ona do sędziego kapturowego różańskiego, Kazimierza Budzyńskiego, AGAD, zakr. grodz. rel., 67, k. 100v (1764 r.).

100 Była własnością stolnika sanockiego Mateusza Guzkowskiego, AGAD, zakr. grodz. rel., 82, k. 594 (1785 r.).

101 AGAD, zakr. grodz. rel., 42, k. 2v.

102 AGAD, zakr. ziem. wiecz. rel., 109, k. 383v (1771 r.); AGAD, zakr. grodz. rel., 67, k. 238v (1765 r.); 66, k. 713 (1771 r.); 66, k. 741 (1771 r.); 73, k. 128 (1775 r.); 79, k. 900v (1783 r.); 81, k. 165v (1785 r.).

${ }_{103}$ AGAD, zakr. grodz. rel., 82, k. 594v. Komody używane były w domach gdańszczan od lat trzydziestych XVIII w., ale w drugiej połowie stulecia jeszcze nie były tam liczne, por.: Szymańska-Barylewska E. 2015, s. 109.

104 AGAD, zakr. grodz. rel., 47, k. 397v (1749 r.); 67, k. 100v (1764 r.); 80, k. 173v (1783 r.); 81, k. 165v (1785 r.); 87, k. 152 (1791 r.).

${ }^{105}$ AGAD, zakr. grodz. rel., 81, k. 166 (1785 r.).

106 Np.: AGAD, zakr. grodz. rel., 67, k. 238v (1765 r.); 79, k. 901 (1783 r.). Sepet ,wielki od karety czarny skórą obity stary" miał chorąży zakroczymski Jakub Jaroszewski, AGAD, zakr. grodz. rel., 61, k. 677 (1759 r.).

107 Jan Bakałowicz miał „biuro jesionowe z antapkami” (AGAD, zakr. ziem. wiecz. rel., 112, k. 251v, 1795 r.), Czesław Ignacy Łempicki „dębowe z okuciem mosiężnym wielkie” (AGAD, zakr. grodz. rel., 66, k. 741, 
Tabela 11.

Liczba kufrów w analizowanych źródłach

Table 11.

Number of trunks in the analysed sources

\begin{tabular}{|l|c|c|c|c|c|}
\hline \multicolumn{1}{|c|}{ Lata } & $\begin{array}{c}\text { Liczba przekazów } \\
\text { ogółem }\end{array}$ & $\begin{array}{c}\text { Liczba sztuk } \\
\text { kufrów }\end{array}$ & $\begin{array}{c}\text { Liczba } \\
\text { przekazów }\end{array}$ & $\begin{array}{c}\text { Procent } \\
\text { przekazów }\end{array}$ & Średnio \\
\hline $1701-1750$ & 71 & 7 & 6 & 8,45 & 1,17 \\
\hline $1751-1800$ & 59 & 62 & 29 & 49,15 & 2,14 \\
\hline Razem & 164 & 69 & 35 & 21,34 & 1,97 \\
\hline
\end{tabular}

Tabela 12.

Liczba sepetów w analizowanych źródłach

Table 12.

Number of sepet chests of drawers in the analysed sources

\begin{tabular}{|l|c|c|c|c|c|}
\hline \multicolumn{1}{|c|}{ Lata } & $\begin{array}{c}\text { Liczba przekazów } \\
\text { ogółem }\end{array}$ & $\begin{array}{c}\text { Liczba sztuk } \\
\text { sepetów }\end{array}$ & $\begin{array}{c}\text { Liczba } \\
\text { przekazów }\end{array}$ & $\begin{array}{c}\text { Procent } \\
\text { przekazów }\end{array}$ & Średnio \\
\hline $1651-1700$ & 29 & 2 & 1 & 3,45 & 2,00 \\
\hline $1701-1750$ & 71 & 7 & 3 & 4,25 & 2,33 \\
\hline $1751-1800$ & 59 & 5 & 4 & 6,78 & 1,25 \\
\hline Razem & 164 & 14 & 8 & 4,88 & 1,75 \\
\hline
\end{tabular}

praktycznych, niewątpliwie zwiększały estetykę wnętrz, o czym świadczą dwa drobiazgowe opisy: „biurko jesionowe do woskowania nowe z szufladami wysuwanymi dużymi od tyłu trzema, czwarta u góry zaś małymi ośmioma a dziewięta skrytka”108, stanowiące własność łowczego przasnyskiego Adama Łaźniewskiego (1783 r.), oraz „biureczko małe wysadzane z kilkoma szufladkami kolbuszowskiej roboty”, należące do Marianny z Kozłowskich Jakackiej $(1788 \text { r. })^{109}$. Tam najprawdopodobniej trzymano ważne dokumenty i pisma.

„Papiery” i gotówkę z reguły jednak przechowywano w szkatułach i szkatułkach ${ }^{110}$, prawdopodobnie odpowiednio okazałych i zabezpieczonych (tab. 13). Trzymano w nich także kornety ${ }^{111}$, wyjątkowo inne artykuły — jedna szkatuła „okowana do korzeni” ${ }^{112}$. Ciekawa jest za-

1771 r.). Do Piotra Maruszewskiego należało biurko oraz „biureczko maleńkie białe” (AGAD, zakr. grodz. rel., 81, k. 166v, 1785 r.), zaś do Felicjana Ołdakowskiego „kantorek alias szafka w której są wszystkie papiery, dębowa po wierzchu drzwiczki czarne dębem sadzane okowana ze wszystkim" (AGAD, zakr. grodz. rel., 42, k. 2v, 1746 r.). Komornik ziemski różański Mateusz Tański miał „kantorek od papierów na nóżkach z szufladami zielono malowany” (AGAD, zakr. grodz. rel., 67, k. 238v, 1765 r.), z kolei „kantorek dębowy powłoka na nim orzechowa” był własnością Józefa Ciszowskiego (AGAD, zakr. grodz. rel., 78, k. 66v, 1778 r.). Bliżej nieopisany „kantorek” spisano wśród ruchomości Mateusza Guzkowskiego (AGAD, zakr. grodz. rel., 82, k. 594v, 1785 r.), zaś „kantorek dobry z zamkami” u komornika ziemi zakroczymskiej Mateusza Śniadowskiego (AGAD, zakr. grodz. rel., 84, k. 166v, 1787 r.). O tego typu meblach dębowych i jesionowych, por.: Barylewska-Szymańska E. 2015, s. 133.

108 AGAD, zakr. grodz. rel., 79, k. 900v (1783 r.).

109 AGAD, zakr. grodz. rel., 81, k. 138 (1788 r.).

110 AGAD, zakr. grodz. rel., 17, k. 298 (1716 r.); 36, k. 235 b-c (1741 r.); 38, k. 118 (1742 r.); 52, k. 506v

(1753 r.); 76, k. 1055 (1782 r.); 82, k. 594v (1785 r.); AGAD, zakr. rel., 11, k. 243 (1757 r.).

111 AGAD, zakr. grodz. rel., 8, k. 727 (1701 r.).

112 AGAD, zakr. grodz. rel., 42, k. 2v (1746 r.). 
wartość jednej z takich szkatuł, należącej do Apolonii z Fredrów Strzałkowskiej w 1741 r.: „gdańska dobra z szufladami, w której szkaplerze i różne rzymskie świętości”113. Jak się wydaje, dla lepszej ochrony znajdujących się w nich rzeczy, szkatułki były „okowane” ${ }^{\prime 14}$.

Tabela 13.

Liczba szkatuł i szkatułek w analizowanych źródłach

Table 13.

Number of caskets and boxes in the analysed sources

\begin{tabular}{|l|c|c|c|c|c|}
\hline \multicolumn{1}{|c|}{ Lata } & $\begin{array}{c}\text { Liczba przekazów } \\
\text { ogółem }\end{array}$ & $\begin{array}{c}\text { Liczba sztuk } \\
\text { szkatuł } \\
\text { i szkatułek }\end{array}$ & $\begin{array}{c}\text { Liczba } \\
\text { przekazów }\end{array}$ & $\begin{array}{c}\text { Procent } \\
\text { przekazów }\end{array}$ & Średnio \\
\hline $1651-1700$ & 29 & 12 & 7 & 24,14 & 1,71 \\
\hline $1701-1750$ & 71 & 26 & 16 & 22,54 & 1,63 \\
\hline $1751-1800$ & 59 & 17 & 11 & 18,64 & 1,55 \\
\hline Razem & 164 & 55 & 34 & 20,73 & 1,62 \\
\hline
\end{tabular}

Do przechowywania dokumentów służyły też sprzęty określone w omawianych źródłach jako „kałamarze”, oznaczające rodzaj przyborników. W dwóch przypadkach opisano je jako: „kałamarz do konserwacji papierów czarny skórzany”, należący do chorążego zakroczymskiego Jakuba Jaroszewskiego (w 1759 r.) ${ }^{115}$, oraz „kałamarz od papierów drewniany w skórą czarną oprawny z szufladką", własność burgrabiego grodzkiego zakroczymskiego Piotra Gawłowskiego (z 1782 r. $)^{116}$. Dobrą ilustracją wpływu, nawet na takie drobne przedmioty gustów estetycznych ówczesnych pokoleń, jest opis trzech wyrobów zawarty w inwentarzu pośmiertnym majora regimentu łanowego koronnego Czesława Ignacego Łempickiego z 1771 r.: „kałamarz z piaseczniczką i dzwonkiem i tacką porcelany saskiej, [...] kałamarz mosiężny z piasecznicą, kałamarz marmurowy"117.

W analizowanych przekazach wymieniono zaledwie osiem zegarów wśród ruchomości należących do sześciu osób: podkomorzego chełmińskiego i generała autoramentu cudzoziemskiego Krzysztofa Koryckiego (1677 r.), stolnika nowogrodzkiego Franciszka Czaczkowskiego (1726 r.), Apolonii, wdowy po Aleksandrze Strzałkowskim, chorążym zakroczymskim (1741 r.), oraz majora regimentu łanowego koronnego Czesława Ignacego Łempickiego (1764 r.), sędziego kapturowego różańskiego Kazimierza Budzyńskiego (1771 r.), a także stolnika sanockiego Mateusza Guzkowskiego (1785 r.) $)^{118}$. Z dużym prawdopodobieństwem można ich zaliczyć do najzamożniejszej szlachty w tej ziemi. Częściej w domach szlachty zakroczymskiej używane były zegarki osobiste ${ }^{119}$.

113 AGAD, zakr. grodz. rel., 36, k. 235bv (1741 r.).

114 Np.: „,szkatuła w kratę żelazną obita” spisana u Apolonii Strzałkowskiej z Fredrów, wdowy po Aleksandrze chorążym zakroczymskim, AGAD, zakr. grodz. rel., 36, k. 235 b (1741 r.).

115 AGAD, zakr. grodz. rel., 61, k. 677v (1759 r.).

116 Warto wspomnieć, że miał on także drugi kałamarz, ale opisany jako „porcynelowy biały malowany”, AGAD, zakr. grodz. rel., 76, k. 1055 (1782 r.).

117 AGAD, zakr. grodz. rel., 66, k. 739v i 741 (1771 r.).

118 AGAD, zakr. grodz. rel., 5, k. 460v (1677 r.); 25, k. 144b (1726 r.); 36, k. 235a (1741 r.); 67, k. 100v (1764 r.); 66, k. 741 (1771 r.); 82, k. 591v (1785 r.).

11919 chronometrów było w posiadaniu 15 osób: „mosiężny pektoralik” zanotowano u podstolego ciechanowskiego Pawła Lasockiego (AGAD, zakr. grodz. rel., 23, k. 453, 1724 r.), a „,mały srebrny” u Franciszka Czaczkowskiego (AGAD, zakr. grodz. rel., 25, k. 144b, 1726 r.). Przedmiot określony jako „zegarek” (AGAD, 
Łóżka rzadko wymieniano w analizowanych źródłach ${ }^{120}$. Opisy inwentarzowe dotyczące tych podstawowych sprzętów służących odpoczynkowi, a użytkowanych w omawianych siedzibach, przeważnie są dość ogólnikowe; wskazują z reguły na ich wielkość (małe — duże lub ,pojedyncze” — „małżeńskie”) ${ }^{121}$, typ lub sposób wykonania (żelazne, dębowe, saskie, „,na sznurach”) ${ }^{122}$ (tab. 14).

Tabela 14.

Liczba łóżek w analizowanych źródłach

Table 14.

Number of beds in the analysed sources

\begin{tabular}{|l|c|c|c|c|c|}
\hline \multicolumn{1}{|c|}{ Lata } & $\begin{array}{c}\text { Liczba przekazów } \\
\text { ogółem }\end{array}$ & $\begin{array}{c}\text { Liczba sztuk } \\
\text { łóżek }\end{array}$ & $\begin{array}{c}\text { Liczba } \\
\text { przekazów }\end{array}$ & $\begin{array}{c}\text { Procent } \\
\text { przekazów }\end{array}$ & Średnio \\
\hline $1651-1700$ & 29 & 1 & 1 & 3,45 & 1,00 \\
\hline $1701-1750$ & 71 & 10 & 6 & 8,45 & 1,67 \\
\hline $1751-1800$ & 59 & 41 & 15 & 25,42 & 2,73 \\
\hline Razem & 164 & 52 & 22 & 13,41 & 2,36 \\
\hline
\end{tabular}

Dużo częściej w uwzględnionych przekazach wspominano o zasobach pościeli i bielizny pościelowej. Bety, kołdry, poduszki, piernaty, pierzyny szyto z różnych tkanin, najczęściej cwelichu i jedwabnej kitajki ${ }^{123}$. Najpopularniejszym w tym okresie kolorem był karmazyn,

zakr. rel., 11, k. 184, 1733 r.) oraz „,srebrny” miał Michał Myszczyński (AGAD, zakr. grodz. rel., 38, k. 283, 1735 r.), „ze srebrnym łańcuszkiem” - cześnik nowogrodzki Stanisław Golimski (AGAD, zakr. grodz. rel., 47, k. 395, 1749 r.), natomiast „srebrny staroświecki przedałam za tf 36” wzmiankowano u chorążego zakroczymskiego Jakuba Jaroszewskiego (AGAD, zakr. grodz. rel., 61, k. 677v, 1759 r.). „Złoty pektoralik” był własnością Mateusza Tańskiego (AGAD, zakr. grodz. rel., 67, k. 238, 1765 r.), „staroświecka robota srebrny” Jacka Sobolewskiego (AGAD, zakr. grodz. rel., 73, k. 129, 1775 r.), zaś „w kopercie zielonej pozłacanej” i ,srebrny z kopertami 2-ma w srebrna i czapowa zielona z łańcuszkiem srebrnym popsuty, reperacji potrzebny" — burgrabiego grodzkiego zakroczymskiego Piotra Gawłowskiego (AGAD, zakr. grodz. rel., 76, k. 1054v, 1782 r.). „Szczerozłoty w kopercie bez łańcuszka” miał Józef Ciszowski (AGAD, zakr. grodz. rel., 78, k. 64, 1778 r.), „złoty” — łowczy przasnyski Adam Łaźniewski (AGAD, zakr. grodz. rel., 79, k. 900v, 1783 r.), „srebrny z 2-ma kopertami, 1-na czapę czarną, 2-ga srebrna staroświeckiej roboty zł. 54” — Mikołaj Budny (AGAD, zakr. grodz. rel., 81, k. 112, 1785 r.), „srebrny o 2-ch kopertach” — Piotr Maruszewski (AGAD, zakr. grodz. rel., 81, k. 161, 1785 r.), ,z emalią zloty” i „męski zloty” — Mateusz Guzkowski (AGAD, zakr. grodz. rel., 82, k. 591v, 1785 r.), „złoty gładki z łańcuszkiem” — Jan Bakałowicz (AGAD, zakr. ziem. wiecz. rel., 112 , k. 251v, 1795 r.).

120 Podobnie było w Wielkopolsce, Dumanowski J. 2006, s. 66.

121 Tak opisano dwa łóżka należące do Piotra Maruszewskiego, AGAD, zakr. grodz. rel., 81, k. 166 (1785 r.).

122 Odpowiednio: łóżko ,żelazne [o wartości - D.G.] zł 116” miała Jaroszewska, chorążycowa zakroczymska (AGAD, zakr. ziem. wiecz. rel., 113, k. 175, 1795 r.), ,żelazne” — Jan Bakałowicz (AGAD, zakr. ziem. wiecz. rel., 112, k. 251v, 1795 r.), Józef Ciszowski (AGAD, zakr. grodz. rel., 78, k. 66v, 1778 r.) i Mateusz Guzkowski (AGAD, zakr. grodz. rel., 82, k. 593v, 1785 r.), ,saskie żelazne kotara z kołdrą do niego płociankowa” oraz „dębowe” - Czesław Ignacy Łempicki (AGAD, zakr. grodz. rel., 66, k. 740v, 1771 r.), ,żelazne zieloną kitajką powleczone” — Adam Łaźniewski (AGAD, zakr. grodz. rel., 79, k. 901v, 1783 r.); „ze sznurami” — Jan Grabczewski (AGAD, zakr. grodz. rel., 87, k. 152v, 1791 r.), zaś „mniejsze na sznurach” — Antoni Drozdowski (AGAD, zakr. rel. 11, k. 242v, 1757 r.).

${ }^{123}$ Najwięcej pościeli było wykonanej z cwelichu — 53 sztuki, pozostałe z kitajki — 40, z musułbasu — 38, z bagazji - 13, z atłasu i półatlasia - 10 sztuk, z astrachania -6, z cycu -5, z barchanu $-4, \mathrm{z}$ grodeturu -4 , z drelichu -3 , z barakanu — 2 i z rasy - 1. Tkaniny jedwabne użyto do uszycia pościeli odnotowanej przede wszystkim u osób pełniących urzędy i aspirujących do zajęcia wysokiego miejsca w hierarchii zamożności. 
a liczba pościeli o takim zabarwieniu znacznie przewyższa pozostałe ${ }^{124}$ (tab. 15). Liczba sztuk pościeli u poszczególnych osób była ogromnie zróżnicowana, od jednej kołdry (co raczej wskazuje na niekompletność zapisu) do ponad 30. W ponad połowie relacji liczba ta wynosiła od 4 do 12. Największy zasób: jeden bet, cztery kołdry, dwa piernaty, sześć pierzyn, 14 poduszek

Tabela 15 .

Liczba pościeli w analizowanych źródłach

Table 15.

Number of bedding in the analysed sources

\begin{tabular}{|l|c|c|c|c|c|}
\hline \multicolumn{1}{|c|}{ Lata } & $\begin{array}{c}\text { Liczba przekazów } \\
\text { ogółem }\end{array}$ & $\begin{array}{c}\text { Liczba sztuk } \\
\text { pościeli }\end{array}$ & $\begin{array}{c}\text { Liczba } \\
\text { przekazów }\end{array}$ & $\begin{array}{c}\text { Procent } \\
\text { przekazów }\end{array}$ & Średnio \\
\hline $1651-1700$ & 29 & 7 & 4 & 13,79 & 1,75 \\
\hline $1701-1750$ & 71 & 154 & 25 & 35,21 & 6,16 \\
\hline $1751-1800$ & 59 & 315 & 32 & 54,24 & 9,84 \\
\hline Razem & 164 & 476 & 61 & 37,20 & 7,80 \\
\hline
\end{tabular}

i cztery wały (łącznie 31 sztuk) zgromadził Piotr Maruszewski (w 1785 r.) $)^{125}$. Tylko o jedną sztukę mniej miał łowczy przasnyski Adam Łaźniewski (w 1783 r.). Należał do niego: jeden bet, cztery kołdry, w tym po jednej uszytej z adamaszku i grodeturu, siedem piernatów, dwie pierzyny i 16 poduszek $^{126}$. Rzadziej odnotowywano bieliznę pościelową (tab. 16): poszewki,

Tabela 16.

Liczba bielizny pościelowej w analizowanych źródłach

Table 16.

Number of bed linen in the analysed sources

\begin{tabular}{|l|c|c|c|c|c|}
\hline \multicolumn{1}{|c|}{ Lata } & $\begin{array}{c}\text { Liczba przekazów } \\
\text { ogólem }\end{array}$ & $\begin{array}{c}\text { Liczba sztuk } \\
\text { bielizny } \\
\text { pościelowej }\end{array}$ & $\begin{array}{c}\text { Liczba } \\
\text { przekazów }\end{array}$ & $\begin{array}{c}\text { Procent } \\
\text { przekazów }\end{array}$ & Średnio \\
\hline $1651-1700$ & 29 & 6 & 1 & 3,45 & 0,00 \\
\hline $1701-1750$ & 71 & 185 & 16 & 22,54 & 11,56 \\
\hline $1751-1800$ & 59 & 315 & 26 & 44,07 & 12,12 \\
\hline Razem & 159 & 506 & 43 & 27,04 & 11,77 \\
\hline
\end{tabular}

powłoczki i prześcieradła, uszyte przede wszystkim z różnych gatunków płótna ${ }^{127}$. W tym zakresie również można zaobserwować znaczne różnice w wyposażeniu domostw. W ponad 20 przypadkach liczba sztuk bielizny pościelowej nie przekraczała pięciu, zaś w dziewięciu innych — ponad 20. Najwięcej, bo łącznie 46, w tym: 12 prześcieradeł lnianych, osiem powłoczek szwabskich i 26 cienkich lnianych, miał Felicjan Ołdakowski (w 1746 r.) ${ }^{128}$.

${ }^{124}$ Dane o kolorze podano tylko dla 46 sztuk pościeli. W kolorze karmazynowym było jej 36, w żółtym i białym - po 4, zaś w zielonym - 2 .

125 AGAD, zakr. grodz. rel., 81, k. 164v (1785 r.).

126 AGAD, zakr. grodz. rel., 79, k. 901v (1783 r.).

127 Odnotowano 67 sztuk bielizny pościelowej wykonanej z płótna pruskiego, 63 z olęderskiego, 46 z lnianego, 14 ze szwabskiego, 9 ze śląskiego, 4 z kolońskiego, 3 z podgórskiego oraz 2 z konopnego.

${ }^{128}$ AGAD, zakr. grodz. rel., 42, k. 1v (1746 r.). 
Tabela 17.

Liczba bielizny stołowej w analizowanych źródłach

Table 17.

Number of table linen in the analysed sources

\begin{tabular}{|l|c|c|c|c|c|}
\hline \multicolumn{1}{|c|}{ Lata } & $\begin{array}{c}\text { Liczba przekazów } \\
\text { ogółem }\end{array}$ & $\begin{array}{c}\text { Liczba sztuk } \\
\text { bielizny stołowej }\end{array}$ & $\begin{array}{c}\text { Liczba } \\
\text { przekazów }\end{array}$ & $\begin{array}{c}\text { Procent } \\
\text { przekazów }\end{array}$ & Średnio \\
\hline $1651-1700$ & 29 & 2 & 1 & 3,45 & 0,00 \\
\hline $1701-1750$ & 71 & 148 & 11 & 15,49 & 13,45 \\
\hline $1751-1800$ & 59 & 459 & 22 & 37,29 & 20,86 \\
\hline Razem & 164 & 609 & 34 & 20,73 & 17,91 \\
\hline
\end{tabular}

Bieliznę stołową (tab. 17) szyto przede wszystkim z płótna. Wzmiankowano obrusy i serwety, opatrując je także określeniami wskazującymi miejsce ich wykonania: osiem obrusów i 72 serwety „gdańskie”, 27 obrusów i 39 serwet „olenderskich”, 12 obrusów i 39 serwet „pruskich”, osiem obrusów i 12 serwet ,podgórskich” oraz trzy „śląskie”. Ponadto, choć zdecydowanie rzadziej, robiono je z tkanin jedwabnych. I tak, adamaszkowy obrus miał major Czesław Ignacy Łempicki (w 1771 r.) ${ }^{129}$, zaś ,olenderski adamaszkowy” oraz trzy tuziny takich serwet stolnik sanocki Mateusz Guzkowski (w 1785 r.); ten ostatni miał ponadto karmazynową serwetę $\mathrm{z}$ atlasu ${ }^{130}$. Liczba obrusów w domach szlacheckich na badanym terenie była znacznie mniejsza niż było to uważane np. za ilość odpowiednią dla tego stanu w Rzeszy Niemieckiej wiek wcześniej ${ }^{131}$.

Na kartach uwzględnionych dokumentów zarejestrowano niewiele przedmiotów niezbędnych do utrzymania higieny osobistej oraz ubrań w czystości. Czy to następstwo niewielkiej, z punktu widzenia naszych czasów, wiedzy i braku nawyku codziennych czynności higienicznych, czy też kolejny przykład zawodności, niekompletności rejestrów mienia? Sądzę, że istotne były oba te czynniki. Większość tych rzeczy wymieniono w spisach przeprowadzonych w XVIII w. Był to jeden lawaterz (w 1785 r. $)^{132}, 14$ miednic z nalewkami w 10 domach ${ }^{133}$, osiem brzytew u pięciu osób $^{134}$ i trzy urynały ${ }^{135}$. Ręczniki stwierdzono tylko w co ósmym przekazie (tab. 18). Na ogół było ich od jednego do trzech, gdyż tyle zapisano w dwóch trzecich wszystkich dokumentów, w których je wymieniono. Niekiedy podawano ich pochodzenie, stąd wiadomo o „krakowskich" 136 , „olenderskich"137, „podgórskich”138 oraz ,pruskich”139. Były one tanie, skoro w 1743 r. dwa

129"AGAD, zakr. grodz. rel., 66, k. 740v (1771 r.).

${ }^{130}$ AGAD, zakr. grodz. rel., 82, k. 594v i 595 (1785 r.).

131 Klonder A. 2001, s. 82.

132 AGAD, zakr. grodz. rel., 82, k. 593 (1785 r.).

133 AGAD, zakr. grodz. wiecz., 104, k. 162v (1691 r.); 107, k. 166v-167 (1691 r.); zakr. grodz. rel., 8, k. 270v (1699 r.); 8, k. 727 (1701 r.); 22, k. 43v (1722 r.); 25, k. 144b (1726 r.); 66, k. 739v (1771 r.); 78, k. 65, (1778 r.); 82 , k. 593 (1785 r.).

134 AGAD, zakr. grodz. rel., 49, k. 260 (1750 r.); 61, k. 346 (1768 r.); 67, k. 100v (1764 r.); 67, k. 238 (1765 r.); 79, k. 900 (1783 r.).

${ }_{135}$ AGAD, zakr. grodz. rel., 47, k. 397 (1749 r.); 61, k. 678 (1759 r.); 81, k. 167v (1785 r.).

1364 sztuki takich ręczników miała Marianna Skarzyńska, AGAD, zakr. grodz. rel., 66, k. 701v (1768 r.).

1376 takich miał Franciszek Czaczkowski, AGAD, zakr. grodz. rel., 25, k. 144c (1726 r.), zaś jeden ,zażywany zły" Antoni Łazowski, AGAD, zakr. grodz. rel. 66, k. 632 (1770 r.).

1382 ręczniki opisane w ten sposób należały do Magdaleny Bobrowskiej (AGAD, zakr. grodz. rel., 65, k. 60, 1759 r.), 1 do Apolonii, wdowy po Aleksandrze Strzałkowskim (AGAD, zakr. grodz. rel., 36, k. 235c, 1741 r.), zas 2 do Adama Łaźniewskiego (AGAD, zakr. grodz. rel., 79, k. 901v, 1783 r.).

139 Pół tuzina odnotowano u Salomei Januszewskiej z Jaroszewskich, AGAD, zakr. grodz. rel., 52, k. 435 (1748 r.). 
ręczniki wyceniono na 6 zł $^{140}$, zaś jeden w 1791 r. na 2 zł i 15 gr $^{141}$. Do czynności związanych z dbałością o czystość służyły też przechowywane w domach: balie ${ }^{142}$, kociołki do prania ${ }^{143}$ i wanienki ${ }^{144}$, żelazka do prasowania ${ }^{145}$, magle ${ }^{146}$ oraz szczotki do „,chędożenia” odzieży ${ }^{147}$.

Tabela 18.

Liczba sztuk ręczników w analizowanych źródłach

Table 18.

Number of towels in the analysed sources

\begin{tabular}{|l|c|c|c|c|c|}
\hline \multicolumn{1}{|c|}{ Lata } & $\begin{array}{c}\text { Liczba przekazów } \\
\text { ogółem }\end{array}$ & $\begin{array}{c}\text { Liczba sztuk } \\
\text { ręczników }\end{array}$ & $\begin{array}{c}\text { Liczba } \\
\text { przekazów }\end{array}$ & $\begin{array}{c}\text { Procent } \\
\text { przekazów }\end{array}$ & Średnio \\
\hline $1701-1750$ & 71 & 42 & 11 & 15,49 & 3,82 \\
\hline $1751-1800$ & 59 & 45 & 10 & 16,95 & 4,50 \\
\hline Razem & 164 & 87 & 21 & 12,80 & 4,14 \\
\hline
\end{tabular}

Naczynia pełniące funkcję zastawy stołowej były jednym ze składników majątku ruchomego, który najczęściej uwzględniano w rejestrach mienia. Niekiedy podawano tylko ogólne określenia. Na przykład w 1695 r. w inwentarzu pośmiertnym Wojciecha Kowalewskiego wymieniono „,cyny sztuk 12 angielskiej”148, a „puzdro półmisków” u Heleny Oborskiej, wdowy po Wojciechu Dunin-Miączyńskim w 1691 r. $^{149}$ (tab. 19). Z reguły w analizowanych źródłach wymieniano zastawę zrobioną z cyny. Jej podstawowymi elementami było przeciętnie 10 talerzy i 10 półmisków oraz po trzy misy i przystawki. O rozmiarach i kształtach tych przedmiotów niewiele wiadomo, gdyż sformułowania na ten temat są mało precyzyjnie. Wynika z nich jedynie, że misy niekiedy miały uszy ${ }^{150}$ lub obręcze ${ }^{151}$, bywały płaskie ${ }^{152}$ bądź głębokie ${ }^{153}$. Powszechnym

140 AGAD, zakr. grodz. wiecz., 117, k. 276v.

141 AGAD, zakr. ziem. wiecz. rel., 114, k. 129v.

142 AGAD, zakr. grodz. rel., 47, k. 398 (1749 r.); 66, k. 713 (1771 r.).

143 Określano jako „od chust”, AGAD, zakr. grodz. rel., 25, k. 144d (1726 r.); 36, k. 235cv (1741 r.); 44, k. 58v (1751 r.); 66, k. 712v (1771 r.); 82, k. 592v (1785 r.).

144 AGAD, zakr. grodz. rel., 38, k. 118 (1742 r.).

145 Wyróżniono żelazka przeznaczone do prasowania „kornetów” (AGAD, zakr. grodz. rel., 66, k. 701v, 1768 r.), „bielizny” (AGAD, zakr. grodz. rel., 79, k. 899v, 1783 r.) oraz „,sukien” (AGAD, zakr. grodz. rel., 81, k. 167, 1785 r.). Wymieniono takze żelazka „mosiężne do prasowania z duszami” (AGAD, zakr. grodz. rel., 87, k. 151,1791 r.).

${ }^{146}$ AGAD, zakr. grodz. rel., 21, k. 98 (1718 r.); 42, k. 2v (1746 r.); 47, k. 397v (1749 r.); 62, k. 80 (1760 r.); 81, k. 166 (1785 r.).

147 AGAD, zakr. grodz. rel., 25, k. 144d (1726 r.), 42, k. 2 (1746 r.); 67, k. 100 (1764 r.); 76, k. 1053v (1782 r.); 81, k. 160v (1785 r.).

148 AGAD, zakr. grodz. wiecz., 108, k. 179.

149 AGAD, zakr. grodz. wiecz., 107, k. 166v (1691 r.).

150 Taką misę miał łowczy przasnyski Adam Łaźniewski, AGAD, zakr. grodz. rel., 79, k. 899v (1783 r.).

151 Odnotowano ją także u Adama Łaźniewskiego (AGAD, zakr. grodz. rel., 79, k. 899v, 1783 r.) oraz u Józefa Ciszowskiego (AGAD, zakr. grodz. rel., 78, k. 66, 1778 r.). W inwentarzu pośmiertnym Apolonii Strzałkowskiej z Fredrów, wdowy po chorążym zakroczymskim Aleksandrze, z 1741 r. wymieniono 5 półmisków „z obręczami”, AGAD, zakr. grodz. rel., 36, k. 235cv.

1522 takie misy miał chorąży zakroczymski Jakub Jaroszewski (AGAD, zakr. grodz. rel., 61, k. 677v, 1759 r.), 1 - komornik ziemski różański Mateusz Tański (AGAD, zakr. grodz. rel., 67, k. 238, 1765 r.), 2 - Antonina z Karczewskich Januszewska (AGAD, zakr. grodz. rel., 66, k. 763, 1772 r.), 4 — starosta starorypiński Józef Ciszowski (AGAD, zakr. grodz. rel., 78, k. 66, 1778 r.), zaś aż 6 sztuk Piotr Maruszewski (AGAD, zakr. grodz. rel., 81, k. 163, 1785 r.).

153 AGAD, zakr. grodz. rel., 81, k. 163 (1785 r.). 
uznaniem cieszyły się ówcześnie wyroby z cyny angielskiej, jednak w badanych przekazach wspominano je sporadycznie — tylko w pięciu, łącznie 66 sztuk. To pojedyncze przedmioty ${ }^{154}$. Jedynie burgrabia grodzki zakroczymski Piotr Gawłowski w 1782 r. dysponował kompletem, który tworzyły: dwie misy, sześć półmisków, trzy salaterki oraz po tuzinie talerzy i łyżek ${ }^{155}$.

Tabela 19.

Liczba zastawy stołowej w analizowanych źródłach

Table 19.

Number of tableware in the analysed sources

\begin{tabular}{|l|c|c|c|c|c|}
\hline \multicolumn{1}{|c|}{ Lata } & $\begin{array}{c}\text { Liczba przekazów } \\
\text { ogółem }\end{array}$ & $\begin{array}{c}\text { Liczba sztuk } \\
\text { zastawy stołowej }\end{array}$ & $\begin{array}{c}\text { Liczba } \\
\text { przekazów }\end{array}$ & $\begin{array}{c}\text { Procent } \\
\text { przekazów }\end{array}$ & Średnio \\
\hline $1651-1700$ & 29 & 272 & 17 & 58,62 & 16,00 \\
\hline $1701-1750$ & 71 & 1007 & 42 & 59,15 & 23,98 \\
\hline $1751-1800$ & 59 & 2597 & 42 & 71,19 & 61,83 \\
\hline Razem & 164 & 3877 & 102 & 62,20 & 38,01 \\
\hline
\end{tabular}

Posiadanie srebrnych naczyń stołowych to niewątpliwie przejaw luksusu, jednakże w różnej skali, gdyż w znacznej części analizowanych domostw szlacheckich ograniczony do jednego trzech przedmiotów ${ }^{156}$. Potrzeba okazania splendoru i zamożności mogła być realizowana przez najbardziej rozpowszechnione, ale mniej kosztowne łyżki (tab. 20) i noże ze srebra. Wyroby z tego kruszcu należące do szlachty zakroczymskiej to sztućce: łyżeczki i widelce, oraz naczynia różnego przeznaczenia, w tym: przystawki, półmiski, talerze, salaterki, wazy, blaty, czarki, kubki, puchary, cukierniczki, imbryki i dzbanki. Najwięcej takich przedmiotów, bo 142, było własnością starosty starorypińskiego Józefa Ciszowskiego w 1778 r.: serwis obiadowy, cztery blaty, po dwie wazy i tace, „fajerka srebrna do rozgrzewania potraw”, dwa tuziny półmisków i salaterek, dwie łyżki stołowe i 11 mniejszych, po dwa tuziny noży i grabek oraz noży i widelców, jeden nóż wielki, cukiernica, dwa imbryczki do herbaty, dzbanuszki do kawy i mleka oraz sześć łyżeczek do kawy, wreszcie „waza srebrna wewnątrz wyzłacana na jedną osobę"157. O połowę mniej, bo 71 takich kosztownych elementów, miał stolnik sanocki Mateusz Guzkowski w 1785 r. ${ }^{158}$

W analizowanych źródłach po raz pierwszy naczynia z fajansu zarejestrowano w $1764 \mathrm{r}$. Należały one do sędziego kapturowego różańskiego Kazimierza Budzyńskiego. Było to tuzin talerzy oraz imbryk do herbaty ${ }^{159}$. Z kolei w spisie sporządzonym siedem lat później, u Czesława Ignacego Łempickiego, figurowało: 20 talerzy, pięć półmisków oraz dwa imbryki ${ }^{160}$. Najwięcej wyrobów fajansowych, tzn. 51 sztuk, w tym: wazę z blatem, sześć półmisków, po tuzinie talerzy

154 Oprócz wspomnianego Wojciecha Kowalewskiego, 11 dobrych i 5 złych półmisków mial łowczy przasnyski Adam Łaźniewski (AGAD, zakr. grodz. rel., 79, k. 899v, 1783 r.), ale tylko 2 salaterki miał Antoni Łazowski (AGAD, zakr. grodz. rel., 66, k. 631v, 1770 r.), zaś 1 wazę Czesław Ignacy Łempicki (AGAD, zakr. grodz. rel., 66, k. 739v, 1771 r.).

155 AGAD, zakr. grodz. rel., 76, k. 1054 (1782 r.).

156 Warto tu odwołać się do klasycznej już publikacji: Pośpiech A. 1992b; por. także: Dumanowski J. 2006, s. 69-84; Penkała-Jastrzębska A. 2020, s. 34 i n.

157 AGAD, zakr. grodz. rel., 78, k. 64 (1778 r.).

158 AGAD, zakr. grodz. rel., 82, k. 592 (1785 r.).

159 AGAD, zakr. grodz. rel., 67, k. 100v i 101 (1764 r.). Nie ma pewności, czy to wystarczająca przesłanka do tego, by sądzić, że nowa moda na korzystanie z naczyń wyrabianych z fajansu i porcelany wprowadzona została później niż w innych środowiskach, np. mieszczańskim Gdańska, Warszawy i Poznania, por.: Barylewska-Szymańska E. 2015, s. 115; Gajewska M. 1975, s. 181.

${ }_{160}$ AGAD, zakr. grodz. rel., 66, k. 739v (1771 r.). 
głębokich oraz płaskich, solniczkę oraz 18 filiżanek zgromadził łowczy przasnyski Adam Łaźniewski w 1783 r. ${ }^{161}$ Prawdopodobnie jeszcze więcej w zbliżonym czasie miał stolnik sanocki Mateusz Guzkowski, ale opisano je zbyt ogólnikowo, by móc to dokładnie określić: „,komplet fajansu angielskiego z talerzami tuzinów 7" oraz 12 półmisków i dwie wazy ${ }^{162}$. Na 100 zł wyceniono w 1795 r. talerz farfurowy, dwie wazy, po tuzinie półmisków oraz filiżanek należące do chorążycowej zakroczymskiej Jaroszewskiej ${ }^{163}$. Wielokrotnie przywoływany inwentarz pośmiertny Łempickiego wskazuje, że dysponował on też zastawą porcelanową. W jej skład wchodziła porcelana „saska”, w tym: dwie duże i jedna mała misa, maselniczka, czarka, dwa imbryczki oraz tuzin filiżanek, a ponadto dwa tuziny talerzy „olenderskich” i 16 filiżanek „chińskich”

Tabela 20.

Liczba łyżek w analizowanych źródłach

Table 20.

Number of spoons in the analysed sources

\begin{tabular}{|l|c|c|c|c|c|}
\hline \multicolumn{1}{|c|}{ Lata } & $\begin{array}{c}\text { Liczba przekazów } \\
\text { ogółem }\end{array}$ & $\begin{array}{c}\text { Liczba sztuk } \\
\text { łyżek }\end{array}$ & $\begin{array}{c}\text { Liczba } \\
\text { przekazów }\end{array}$ & $\begin{array}{c}\text { Procent } \\
\text { przekazów }\end{array}$ & Średnio \\
\hline $1651-1700$ & 29 & 36 & 8 & 27,59 & 4,50 \\
\hline $1701-1750$ & 71 & 163 & 27 & 38,03 & 6,04 \\
\hline $1751-1800$ & 59 & 440 & 36 & 61,02 & 12,22 \\
\hline Razem & 159 & 639 & 71 & 44,65 & 9,00 \\
\hline
\end{tabular}

W ówczesnych źródłach używano także kategorii „farfurka”165. Trudno z całą pewnością ustalić zakres znaczeniowy tego słowa; z kontekstu jego stosowania wynika, że głównie w znaczeniu „naczynie”. Podana niekiedy liczba farfurek, np. trzykrotnie po 12 lub 18 sztuk, albo wielokrotność tuzina - 24 i 36 sztuk, może przemawiać za taką interpretacją. Nie ma pewności, czy informację „farfurek czyli talerzy [sztuk? tuzinów? — D.G.] 3” można odnieść do wszystkich przypadków, tym bardziej, że w tym samym źródle zapisano także „farfury gliniane"166. Przykłady z Wielkopolski wskazują, że utożsamianie farfur z talerzami jest prawdopodobne ${ }^{167}$. Trudno też ocenić liczbę tych naczyń w badanych spisach. Używaną z reguły jednostką miary był tuzin, ale w dwóch przekazach nie sprecyzowano, czy chodzi o tuziny, czy o sztuki wyrobów ${ }^{168}$. Z pewnością większą liczbę „farfur” odnotowano w pięciu przekazach z okresu $1746-1785^{169}$.

161 AGAD, zakr. grodz. rel., 79, k. 900 (1783 r.).

162 AGAD, zakr. grodz. rel., 82, k. 594v (1785 r.).

163 AGAD, zakr. ziem. wiecz. rel., 113, k. 175 (1795 r.).

164 AGAD, zakr. grodz. rel., 66, k. 739v (1771 r.).

165 Por.: Dumanowski J. 2006, s. 100-117; Roćko A. 2013, s. 127 i n.; Penkała A. 2016, s. 161 i n.

166 AGAD, zakr. ziem. wiecz. rel., 108, k. 142v (1774 r.).

167 Dumanowski J. 2006, s. 92.

168 Dwa tuziny lub sztuki „farfur” były w domu Stanisława Rostkowskiego (AGAD, zakr. ziem. wiecz. rel., 105, k. 306, 1738 r.), z kolei trzy u Jana Lopackiego (AGAD, zakr. ziem. wiecz. rel., 108, k. 142v, 1774 r.).

169 Takie wyroby zarejestrowano: u Anny Komorowskiej — „farfurka gdańska tuzinów 2 jedne cienkie drugie ordynaryjne” (AGAD, zakr. grodz. rel., 60, k. 805, 1759 r.), u Magdaleny Bobrowskiej „farfurka gdańska tuzin” (AGAD, zakr. grodz. rel., 65, k. 60, 1759 r.), u Franciszka Czaczkowskiego — „farfurka półtora tuzina” (AGAD, zakr. grodz. rel., 25, k. 144d, 1726 r.), u Felicjana Ołdakowskiego — „farfurka tuzinów 2” (AGAD, zakr. grodz. rel., 42, k. 2v, 1746 r.), u starościca mścisławskiego Krzysztofa Wołłowicza — „farfurka zakroczymska par 6” oraz „gdańska 16” i ,prosta tuzinów 2” (AGAD, zakr. grodz. rel., 66, k. 712v, 1771 r.), u Piotra Maruszewskiego — „farfurka fabryki warszawskiej tuzinów 3, fabryki zakroczymskiej tuzinów 5” (AGAD, zakr. grodz. rel., 81, k. 167v, 1785 r.). 
Przypuszczalnie nietrwałość, podatność na stłuczenie oraz niewielka wartość niektórych naczyń szklanych powodowały, że w badanych źródłach wymieniono je tylko w pięciu przekazach, pochodzących z lat od 1681 do 1785 . Były to dzbanek, flaszka, karafka, kufle i kieliszki ${ }^{170}$.

W domach objętych spisami używano także mis i talerzy glinianych ${ }^{171}$, zapewne pospolitych wyrobów ceramicznych, oraz drewnianych ${ }^{172}$. Zapisane w dziewięciu przekazach mogły służyć czeladzi bądź miały zastosowanie jako naczynia kuchenne lub spiżarniane (do przechowywania produktów żywnościowych). Od lat czterdziestych XVIII w. na stołach szlachty w ziemi zakroczymskiej pojawiły się wazy, a nieco później także blaty, solniczki, maselniczki, salaterki i cukierniczki. W dwóch przekazach zapisano pojedyncze sztuki srebrnych i miedzianych garnuszków ${ }^{173}$, ale liczniejsze wykonane były z gliny ${ }^{174}$. Do picia wody, piwa, wina, gorzałki służyły srebrne ${ }^{175}$ i pozłacane ${ }^{176}$ lub cynowe ${ }^{177}$ kubki oraz kufle cynowe albo szklane z cynowymi pokrywkami ${ }^{178}$. Na wyróżnienie zasługuje tzw. kufel wiwatowy, opisany jako „kryształowy z przykryciem cynowym z napisem Vivat”, w 1785 r. należący do Piotra Maruszewskiego ${ }^{179}$. Napoje trzymano, a niekiedy i podawano na stół we flaszach o zróżnicowanej pojemności (od pół kwarty do nawet czterech garncy) i w dzbanach. Dość rzadko zapisano, z jakich surowców je wykonano ${ }^{180}$. Tylko w dwóch przekazach nadmieniono o karafkach ${ }^{181}$. Flasze miały też niekiedy inne przeznaczenie, np. trzymano w nich oliwę $e^{182}$.

Stawiane na stołach fajerki zapobiegały stygnięciu potraw. Były one zrobione ze srebra, mosiądzu, żelaza i blachy ${ }^{183}$.

${ }^{170}$ Szklane elementy zastawy stołowej mieli: Kacper Kruszeński (AGAD, zakr. grodz. rel., 8, k. 285, 1681 r.), Felicjan Ołdakowski (AGAD, zakr. grodz. rel., 42, k. 2v, 1746 r.), podwojewodzic warszawski Kasper Dybowski (AGAD, zakr. grodz. rel., 52, k. 506v, 1753 r.), łowczy przasnyski Adam Łaźniewski (AGAD, zakr. grodz. rel., 79, k. 900, 1783 r.) i Piotr Maruszewski (AGAD, zakr. grodz. rel., 81, k. 167v, 1785 r.).

171 AGAD, zakr. grodz. rel., 8, k. 285 (1681 r.); 38, k. 118 (1742 r.); 67, k. 101 (1764 r.); 81, k. 167v (1785 r.).

172 AGAD, zakr. grodz. wiecz., 106, k. 483v (1685 r.); AGAD, zakr. grodz. rel., 17, k. 297v (1716 r.); 21 , k. 91v (1718 r.); 23, k. 310 (1723 r.); AGAD, zakr. ziem. wiecz. rel., 105, k. 306 (1738 r.).

173 Garnuszek „,mały srebrny zły z przykryciem” należał do Aleksandra Łuszczewskiego (AGAD, zakr. grodz. wiecz., 108, k. 544v, 1697 r.), zaś miedziany do łowczego przasnyskiego Adama Łaźniewskiego (AGAD, zakr. grodz. rel., 79, k. 899v, 1783 r.).

17416 garnków polewanych oraz 7 nazwanych ,prostymi” miał Piotr Maruszewski, AGAD, zakr. grodz. rel., 81, k. 167v (1785 r.).

${ }^{175}$ Kwartowy kubek miał skarbnik rzeczycki Jan Michał Joduszko (AGAD, zakr. grodz. rel., 16, k. 943v, 1729 r.), po 2 kwartowe oraz półkwartowe oraz opisane jako „na gałązkach rozłożystych z nakrywadłami półkwartowych srebrnych” miał Franciszek Czaczkowski (AGAD, zakr. grodz. rel., 25, k. 144a, 1726 r.), ,srebrny z osobami duży" miała Anna z Lubeckich Łatynowa (AGAD, zakr. grodz. wiecz., 117, k. 276v, 1743 r.), jeden miał Czesław Ignacy Łempicki (AGAD, zakr. grodz. rel., 66, k. 739v, 1771 r.), zaś 4 Mateusz Guzkowski (AGAD, zakr. grodz. rel., 82, k. 592, 1785 r.).

${ }^{176}$ Kubek o wartości 4 czerwonych złotych miał Franciszek Czaczkowski (AGAD, zakr. grodz. rel., 25, k. 144a, 1726 r.) oraz „wyzłacany wewnątrz” Apolonia Strzałkowska (AGAD, zakr. grodz. rel., 36, k. 235a, $1741 \mathrm{r}$.).

177 AGAD, zakr. ziem. wiecz. rel., 105; k. 306 (1738 r.); AGAD, zakr. grodz. rel., 81, k. 163 (1785 r.).

178 AGAD, zakr. grodz. wiecz., 108, k. 258 (1695 r.); 117, k. 277v (1743 r.); AGAD, zakr. grodz. rel., 8, k. 285 (1681 r.); 8, k. 866v (1706 r.); 79, k. 900v (1783 r.); 81, k. 167v (1785 r.).

179 AGAD, zakr. grodz. rel., 81, k. 167v (1785 r.).

${ }^{180} \mathrm{Na} 201$ flasz tylko przy 20 wspomniano, że zrobiono je z cyny, 15 flasz z miedzi oraz 6 ze srebra.

181 Mieli je: Czeslaw Ignacy Łempicki, do którego należał ,karafinek w srebro oprawny duży [sztuk — D.G.] 2, karafinka od wina większa [sztuk] 4, karafinka mniejsza [sztuk] 6" (AGAD, zakr. grodz. rel., 66, k. 739v, 1771 r.) oraz łowczy przasnyski Adam Łaźniewski — „karafnik z postumentem cynowy, karafnik, szklany z postumentem cynowym" (AGAD, zakr. grodz. rel., 79, k. 900, 1783 r.).

182 AGAD, zakr. grodz. rel., 81, k. 167v (1785 r.).

183 Odnotowano 12 fajerek w ośmiu spisach z lat 1677-1785. Cztery srebrne znajdowały się (po jednej sztuce) wśród ruchomości Krzysztofa Koryckiego, podkomorzego chełminskiego (AGAD, zakr. grodz. rel., 5, 
Spośród sztućców powszechnie używane były łyżki. O ile w XVII w. w analizowanych przekazach zarejestrowano wyłącznie srebrne, to w następnym stuleciu, a szczególnie w jego drugiej połowie, liczbowo przeważały nad nimi cynowe. Zjawisko to zaobserwowałem już w spisach inwentarzowych duchowieństwa ${ }^{184}$. Drugie pod względem frekwencji były noże (tab. 21). Charakteryzowały się przeważnie oprawami ze srebra, znaczniej rzadziej z cyny, ale także z drewna lub z rogu. Widelce i grabki notowano niezbyt często, bo dziesięciokrotnie w XVIII w, ale za to niemało — po sześć lub 12 sztuk $^{185}$. Określenie ,grabki” stosowano w odniesieniu do wyrobów srebrnych, spisanych w pięciu przekazach z lat 1724-1795 ${ }^{186}$.

Tabela 21.

Liczba noży w analizowanych źródłach

Table 21.

Number of knives in the analysed sources

\begin{tabular}{|l|c|c|c|c|c|}
\hline \multicolumn{1}{|c|}{ Lata } & $\begin{array}{c}\text { Liczba przekazów } \\
\text { ogółem }\end{array}$ & $\begin{array}{c}\text { Liczba sztuk } \\
\text { noży }\end{array}$ & $\begin{array}{c}\text { Liczba } \\
\text { przekazów }\end{array}$ & $\begin{array}{c}\text { Procent } \\
\text { przekazów }\end{array}$ & Średnio \\
\hline $1651-1700$ & 29 & 0 & 0 & 0,00 & 0,00 \\
\hline $1701-1750$ & 71 & 64 & 10 & 14,08 & 6,40 \\
\hline $1751-1800$ & 59 & 283 & 19 & 32,20 & 14,89 \\
\hline Razem & 164 & 347 & 29 & 17,68 & 11,97 \\
\hline
\end{tabular}

Coraz powszechniejszy w XVIII w. zwyczaj picia herbaty i kawy przyczynił się do wprowadzenia do domów nowych rodzajów utensyliów ${ }^{187}$. To przede wszystkim imbryki do parzenia tych napojów, odnotowane w 12 uwzględnionych dokumentach. Pierwszy raz naczynie to zostało wymienione w 1741 r. w inwentarzu pośmiertnym chorążyny Apolonii Strzałkowskiej z Fredrów ${ }^{188}$. Asortyment zastawy stołowej wzbogacił się również o cukiernice. Najstarsza wzmianka potwierdzająca jej użytkowanie pochodzi z 1746 r. ${ }^{189}$ Był to przedmiot cenny — zrobiony ze srebra i bliżej nieokreślonej „,blachy” oraz z mosiądzu, „,na czterech nóżkach z zameczkiem" ${ }^{\prime 190}$. Poprzez zamykanie chroniono drogi wówczas cukier. Podstawowymi naczyniami do konsumpcji egzotycznych napojów były filiżanki fajansowe bądź porcelanowe, obecne w niewielu siedzibach (sześciu) od roku $1746^{191}$. Przeciętnie było ich po $12^{192}$. Także w drugiej po-

k. 460v, 1677 r.), a także u marszałka Franciszka Bielińskiego (AGAD, zakr. grodz. rel., 23, k. 164v, 1723 r.), stolnika nowogrodzkiego Franciszka Czaczkowskiego (AGAD, zakr. grodz. rel., 25, k. 144c, 1726 r.) i u starosty starorypińskiego Józefa Ciszowskiego (AGAD, zakr. grodz. rel., 78, k. 64v, 1778 r.). Blaszaną fajerkę miał Ignacy Utowicz (AGAD, zakr. grodz. rel., 8, k. 727, 1701 r.), zaś żelazną i mosiężną Antoni Osiecki (AGAD, zakr. grodz. rel., 46, k. 96v, 1750 r.).

184 Główka D. 2004, s. 155.

185 AGAD, zakr. grodz. rel., 17, k. 92 (1715 r.); 23, k. 164 (1723 r.); 23, k. 310 (1723 r.); 66, k. 739v (1771 r.); 78, k. 65 (1778 r.), 76, k. 1054 (1782 r.).

186 AGAD, zakr. grodz. rel., 23, k. 453 (1724 r.); 25, k. 144b (1726 r.); 62, k. 370v (1760 r.); 66, k. 739v

(1771 r.); 78, k. 64v (1778 r.); AGAD, zakr. ziem. wiecz. rel., 112, k. 250v (1795 r.).

187 O obyczajach związanych z piciem kawy, por. np.: Kitowicz J. 1985, s. 242 i n.

188 AGAD, zakr. grodz. rel., 36, k. 235cv (1741 r.).

189 AGAD, zakr. grodz. rel., 42, k. 1v (1746 r.).

190 AGAD, zakr. ziem. wiecz. rel., 112, k. 251 (1795 r.).

191 AGAD, zakr. grodz. rel., 42, k. 1v (1746 r.).

192 Filiżanki odnotowano w liczbie: 8 sztuk u Felicjana Ołdakowskiego (AGAD, zakr. grodz. rel., 42, k. 1v, 1746 r.), 12 z ,saskiej” i 16 z ,chińskiej” porcelany u Czesława Ignacego Łempickiego (AGAD, zakr. grodz. rel., 66, k. 739v, 1771 r.), 10 u sędziego kapturowego różańskiego Kazimierza Budzyńskiego (AGAD, zakr. grodz. 
łowie XVIII w. o wiele częściej niż w pierwszej notowano w źródłach łyżeczki. Niemal wszystkie były wyrobami ze srebra, tylko dwie z tzw. prinzmetalu, czyli stopu miedzi i cynku, w posiadaniu Jana Grąbczewskiego w 1791 r. ${ }^{193}$

W niektórych pomieszczeniach mieszkalnych zajmowanych przez szlachtę zakroczymską znajdowały się przedmioty mające związek z osobistą dewocją. To krucyfiksy odnotowane w sześciu domach oraz relikwiarze, o których wspomniano w trzech dokumentach ${ }^{194}$. Z wyznawaną wiarą związane były obrazy o tematyce sakralnej, wzmiankowane w 25 przekazach. Najwięcej, bo aż 54, miał ich Piotr Maruszewski w 1785 r. ${ }^{195}$ Zazwyczaj było to kilka wizerunków religijnych — od jednego do trzech, wyjątkowo więcej niż osiem ${ }^{196}$. Najczęściej przedstawiały one sceny z życia Chrystusa oraz Matki Bożej, a także świętych, np. Annę, Antoniego, Barbarę, Jana Nepomucena. Wyobrażenie Matki Boskiej Częstochowskiej stwierdzono w ośmiu siedzibach po roku $1720^{197}$. Często jednak pomijano treść spisywanych obrazów, niekiedy informując o sposobie ich wykonania i określając rodzaj malarskiego podłoża: „na płótnie”, „blaszany” lub ,papierowy”.

Trudno powiedzieć, czy gromadzono także malowidła o tematyce świeckiej. Sporadycznie we wnętrzach wisiały portrety „króla i królowej” (w 1751 r.) ${ }^{198}$, czyli Augusta III i Marii Józefy, jak również „Augusta III na gipsie” (w 1785 r.) ${ }^{199}$. Chyba jedynym świadectwem tworzenia galerii przodków jest zbiór sześciu obrazów w domu stolnika sanockiego Mateusza Guzkowskiego (w 1785 r.), opisanych jako ,portret familii”200.

Sprzęty uprzyjemniające czas wolny, tzn. akcesoria do gier oraz do wykonywania muzyki, w analizowanych źródłach ograniczają się do warcabów oraz do kilku instrumentów. Niewątpliwie przedmiotem luksusowym była należąca do podkomorzego chełmińskiego, Krzysztofa Koryckiego, „warczabnica kością sadzona” (1677 r. $)^{201}$. Dwie inne osoby miały prawdopodob-

rel., 67, k. 100v, 1764 r.), 18 „,farfurowych” i 4 z porcelany „saskiej” u łowczego przasnyskiego Adama Łaźniewskiego (AGAD, zakr. grodz. rel., 79, k. 900v, 1783 r.), 2 u Jana Grąbczewskiego (AGAD, zakr. grodz. rel., 87, k. 152v, 1791 r.), 6 wraz z miseczką u Jacka Sobolewskiego (AGAD, zakr. grodz. rel., 73, k. 129v, 1775 r.).

193 Jan Bakałowicz miał 1 łyżeczkę „,do śmietany” (AGAD, zakr. ziem. wiecz. rel., 112, k. 250v, 1795 r.), natomiast pozostali „od kawy”: 1 egzemplarz Franciszek Czaczkowski (AGAD, zakr. grodz. rel., 25, k. 144b, 1726 r.), 6 - starościc mścisławski Krzysztof Wołłowicz (AGAD, zakr. grodz. rel., 66, k. 712v, 1771 r.), 5 - Czesław Ignacy Łempicki (AGAD, zakr. grodz. rel., 66, k. 739v, 1771 r.), 6 - Józef Ciszowski (AGAD, zakr. grodz. rel., 78, k. 64, 1778 r.), 6 - Adam Łaźniewski (AGAD, zakr. grodz. rel., 79, k. 900, 1783 r.), pozłacaną Piotr Maruszewski (AGAD, zakr. grodz. rel., 81, k. 161, 1785 r.). Aż 17 łyżeczek należało do Mateusza Guzkowskiego (AGAD, zakr. grodz. rel., 82, k. 592, 1785 r.) oraz 2 ,precmetalowe” do Jana Grabczewskiego (AGAD, zakr. grodz. rel., 87, k. 152v, 1791 r.).

194 Trzy krucyfiksy, jeden większy i dwa mniejsze, miała Apolonia, wdowa po Aleksandrze Strzałkowskim (AGAD, zakr. grodz. rel., 36, k. 235cv, 1741 r.), cztery opisane jako „większe i mniejsze” odnotowano u Adama Łaźniewskiego (AGAD, zakr. grodz. rel., 79, k. 901, 1783 r.), zaś „10 relikwiarzyków mniejszych” u Piotra Maruszewskiego (AGAD, zakr. grodz. rel., 81, k. 165v, 1785 r.).

195 AGAD, zakr. grodz. rel., 81, k. 165 (1785 r.).

196 Dość liczną kolekcję obrazów o tematyce religijnej, złożoną z 13 w miarę dobrze opisanych przedstawień, miała Apolonia Strzałkowska z Fredrów (AGAD, zakr. grodz. rel., 36, k. 235cv, 1741 r.). Natomiast Barbara Guzkowska pośród rzeczy Mateusza Guzkowskiego wymieniła pięć obrazów określonych enigmatycznie „świętych różnych z ramami” (AGAD, zakr. grodz. rel., 82, k. 593, 1785 r.).

197 Krzysztof Brodowski (AGAD, zakr. rel., 10, k. 361v, 1720 r.), Apolonia Strzałkowska z Fredrów (AGAD, zakr. grodz. rel., 36, k. 235cv, 1741 r.), Antoni Zaremba (AGAD, zakr. grodz. rel., 49, k. 260, 1750 r.), Kasper Dybowski (AGAD, zakr. grodz. rel., 52, k. 506v, 1753 r.), Jakub Jaroszewski (AGAD, zakr. grodz. rel., 61, k. 677, 1759 r.), Kazimierz Budzyński (AGAD, zakr. grodz. rel., 67, k. 100v, 1764 r.), stolnik gostyński Tomasz Stawiński (AGAD, zakr. ziem. wiecz. rel., 109, k. 516, 1776 r.) i Piotr Maruszewski (AGAD, zakr. grodz. rel., 81, k. 165, 1785 r.).

198 AGAD, zakr. grodz. rel., 44, k. 58 (1751 r.).

199 U Piotra Maruszewskiego, AGAD, zakr. grodz. rel., 81, k. 165 (1785 r.).

${ }^{200}$ AGAD, zakr. grodz. rel., 82, k. 593v (1785 r.).

201 AGAD, zakr. grodz. rel., 5, k. 461 (1677 r.). 
nie miej okazałe zestawy: „arcabnicę do zabawy” (Piotr Maruszewski, w 1785 r.) ${ }^{202}$ i „stolik z warcabnicą na nóżkach krzywych" (Czesław Łempicki, w 1771 r.) ${ }^{203}$. Flet i skrzypce odnotowano u Felicjana Ołdakowskiego (1746 r. $)^{204}$, klawikord u Marianny Skarżyńskiej (1768 r. $)^{205}$, zaś dwa instrumenty klawiszowe — „klawikord mały” oraz „fortepiano” u stolnika sanockiego Mateusza Guzowskiego (w 1785 r.) ${ }^{206}$.

Jedynym przedmiotem, który można wiązać z zainteresowaniem nowinkami z dziedziny nauki i techniki, jest ,skrzyneczka czerwona z instrumentami matematycznymi”, wzmiankowana w 1723 r. w inwentarzu pośmiertnym marszałka Franciszka Bielińskiego ${ }^{207}$.

Stosunkowo nieliczne są rzeczy określone jako ,podróżne” i to w niewielu (tylko pięciu) przekazach. Były to: kałamarz, łyżka, puzdro, „półrondelek” oraz „tolet, osobny podróżny w którym noży z grabkami i łyżkami par 12, noże wielkie para, łyżki półmiskowe 2, łyżki mniejsze wazowe 2", będące własnością starosty starorypińskiego Józefa Ciszowskiego ${ }^{208}$.

Rosnące zainteresowanie szlachty, w tym przypadku prowincjonalnej mazowieckiej w drugiej połowie XVII i w XVIII w., instrumentem prawnym, jakim jest inwentarz mienia, nie budzi wątpliwości. Czytelny jest też rosnący z biegiem czasu, coraz większy udział różnych kategorii ruchomości w analizowanych spisach. Czy to efekt dążenia do dokładności i kompletności działań o charakterze prawnym, czy też zmiana w stanie posiadania przedmiotów wcześniej nieznanych, niedostępnych i rzadko spotykanych?

W odniesieniu do szlachty zakroczymskiej nie można stwierdzić tak wysokich wskaźników, jakie zostały wyliczone dla mieszkańców Gdańska bądź dla szlachty wielkopolskiej w XVIII w. ${ }^{209}$

Sugestywnie skreślony przez Jarosława Dumanowskiego obraz przemiany niektórych aspektów kultury materialnej dla tej ostatniej grupy społecznej daje impuls i skalę porównawczą dla scharakteryzowania tej kwestii w odniesieniu do mienia zgromadzonego w siedzibach szlacheckich na Mazowszu. Zaprezentowane w tabelach dane kwantytatywne pozwalają na kilka spostrzeżeń.

Stopniowo zanikały tradycyjne elementy wnętrz, takie jak tkaniny orientalne, używane jako obicia i kobierce. W XVIII w. nie zmieniła się liczba pościeli i bielizny pościelowej, ręczników, szkatuł i szkatułek. Nie minął też zwyczaj trzymania różnych rzeczy w skrzyniach, skoro w połowie przekazów z drugiej połowy tego stulecia były one notowane. W tym samym czasie można zaobserwować rosnącą potrzebę intymności poprzez wydzielanie miejsc parawanami lub osłanianie łóżek pawilonami. W tym półwieczu znacznie częściej używano też kufrów; niemal podwoiła się ich średnia liczba. Podobna sytuacja dotyczy bielizny stołowej. Więcej posiadano też utensyliów stołowych; potroiła się średnia liczba zastawy. Prawie dwukrotnie częściej w źródłach wymieniano łyżki, a ich przeciętna liczba także się zwiększyła. Porównując

202 AGAD, zakr. grodz. rel., 81, k. 166 (1785 r.).

203 AGAD, zakr. grodz. rel., 66, k. 741 (1771 r.).

204 AGAD zakr. grodz. rel., 42, k. 2v (1746 r.).

${ }^{205}$ AGAD, zakr. grodz. rel., 66, k. 701v (1768 r.).

${ }^{206}$ AGAD, zakr. grodz. rel., 82, k. 594v (1785 r.).

207 AGAD, zakr. grodz. rel., 23, k. 164v (1723 r.).

208 „Łyżka składana podróżna” (AGAD, zakr. grodz. rel., 17, k. 92, 1715 r.), ,kałamarz, podróżny” (AGAD, zakr. grodz. rel., 44, k. 58v, 1751 r.), ,puzdro podróżne” (AGAD, zakr. grodz. rel., 78, k. 66v, 1778 r.), „półrondelek podróżny” (AGAD, zakr. grodz. rel., 82, k. 592v, 1785 r.) oraz wspomniany „tolet” (AGAD, zakr. grodz. rel., 78, k. 64v, 1778 r.).

209 Barylewska-Szymańska E. 2015, s. 290 i n.; Dumanowski J. 2006, s. 51-52, 73-74, 85-86, 91-92, 170. 
obie połowy XVIII stulecia podobne wnioski odnoszą się do noży. W latach 1771-1791 niewątpliwie nowością były łyżeczki. Inne ówczesne nowinki, pojawiające wśród domowych sprzętów, to okrągłe lub rozkładane stoły, kilka krzeseł (co najmniej sześć) oraz — w pojedynczych przypadkach — garnitur złożony z kanapy i krzeseł, a także komoda. Korzystano już wówczas, zgodnie z modą, z naczyń fajansowych i porcelanowych. Wyroby srebrne były, jak się wydaje, atrybutem szlachty bardziej majętnej, piastującej urzędy ziemskie; wymieniano ograniczony ich zestaw. W drugiej połowie XVII w. w kilku przekazach odnotowano łyżki srebrne. Większe zasoby sreber stołowych przechowywano w domach dopiero sto lat później.

Zwraca również uwagę używanie od lat czterdziestych XVIII w. tkanin karmazynowych, zarejestrowanych w 27 badanych przekazach. Miały one zastosowanie jako materiały, z których szyto pościel, wykonywano parawany i wyścielano nimi meble siedzeniowe. Zagadnienie to zasługuje na odrębne, szersze ujęcie.

Trzydzieści lat temu, gdy Jubilat organizował konferencję „Nędza i dostatek na ziemiach polskich od średniowiecza po wiek XX", nikt chyba nie wyobrażał sobie licznych osiągnięć i nietuzinkowych ustaleń wynikających ze studiów pożytkujących inwentarze mienia. Zasługa w tym niemała Andrzeja Klondera.

Adres Autora:

dr hab. Dariusz Główka, prof. PAN

Instytut Archeologii i Etnologii PAN

Al. Solidarności 105

00-140 Warszawa

glowka@iaepan.edu.pl

https://orcid.org/0000-0002-1633-5505

\section{BIBLIOGRAFIA}

\section{Źródla archiwalne}

AGAD [Archiwum Główne Akt Dawnych w Warszawie], zakr. grodz. wiecz. [zakroczymskie grodzkie wieczyste], sygn. 74, 81, 92, 94, 97, 104, 106-111, 117, 122.

AGAD [Archiwum Główne Akt Dawnych w Warszawie], zakr. grodz. rel. [zakroczymskie grodzkie relacje], sygn. 4-5, 7-8, 11, 14-17, 20-21, 24, 26-29, 33, 36, 38-42, 44-47, 49-50, 52, 54, $59-62,65-67,69,72-74,76,78-82,84,87$.

AGAD [Archiwum Głównego Akt Dawnych], zakr. rel. [zakroczymskie relationum], sygn. 9-11.

AGAD [Archiwum Głównego Akt Dawnych], zakr. ziem. wiecz. rel. [zakroczymskie ziemskie wieczyste relacje], sygn. 100, 105-106, 108-109, 112-114.

\section{Źródła i opracowania publikowane}

Barylewska-Szymańska Ewa. 2015. Od piwnic po strych. Wnętrza domów gdańskich drugiej połowy XVIII wieku, Gdańsk.

Dumanowski Jarosław. 2006. Świat rzeczy szlachty wielkopolskiej w XVIII wieku, Torun.

Gajewska Mirosława. 1975. Wyposażenie w sprzęty mieszczańskich gospodarstw domowych Poznania $i$ Warszawy w XVIII wieku, [w:] M. Gajewska, W. Kalinowski, E. Kowecka, N. Miks-Rudkowska, Dom i mieszkanie w Polsce (druga połowa XVII-XIX w.), Studia i Materiały z Historii Kultury Materialnej, t. L, Wrocław, s. 145-238.

Główka Dariusz. 2004. Majątek osobisty duchowieństwa katolickiego w Koronie w XVII i XVIII wieku, Studia i Materiały z Historii Kultury Materialnej, t. LX, Warszawa.

Główka Dariusz. 2018. Siedziby szlacheckie w ziemi zakroczymskiej w XVII i XVIII wieku, „,Kwartalnik Historii Kultury Materialnej”, R. LXVI, nr 4, s. 475-486. 
Kitowicz Jędrzej. 1985. Opis obyczajów za panowania Augusta III, Warszawa.

Klonder Andrzej 2001. Mienie godne szlachcica i mieszczanina w krajach Europy Środkowej w XVII wieku, „Kwartalnik Historii Kultury Materialnej”, R. XLXIX, nr 1-2, s. 81-94.

Penkała Anna. 2016. Materia droższa od srebra, ,farfurki” $i$,,porcelanki” na szlacheckich stołach w świetle inwentarzy oblatowanych w krakowskich księgach grodzkich z XVIII w., [w:] Wiktuaty, kuchnia, kultura jedzenia w perspektywie historycznej, red. P. Jędrzejewski, P. Magiera, K. Skrężyna, G. Szuster, Kraków, s. 160-170.

Penkała-Jastrzębska Anna. 2020. Mit srebrnej tyżeczki? Przedmioty prestiżowe w szlacheckich inwentarzach majątkowych z ksiag grodzkich województwa krakowskiego w czasach saskich, „Kwartalnik Historyczny”, R. CXXVII, nr 1, s. 33-62, https://doi.org/10.12775/KH.2020.127.1.02 (dostęp 02.09.2021).

Pielas Jacek. 2018. Wyposażenie i wystrój wnętrz siedzib szlachty sandomierskiej w XVII i pierwszej połowie XVIII wieku, „Kwartalnik Historii Kultury Materialnej”, R. LXVII, nr 1, s. 55-72.

Pośpiech Andrzej. 1992a. Pułapka oczywistości. Pośmiertne spisy ruchomości szlachty wielkopolskiej z XVII wieku, Warszawa.

Pośpiech Andrzej. 1992b. Srebrna łyżka — probierz szlacheckiej zamożności? (Przykład Wielkopolski XVII wieku), [w:] Nędza i dostatek na ziemiach polskich od średniowiecza po wiek XX. Materiaty z sesji zorganizowanej przez IHKM PAN 20-22 maja 1991 r. w Warszawie, red. J. Sztetyło, Warszawa, s. 151-162.

Roćko Agata. 2013, Porcelomania oświeconych, [w:] Codzienność i niecodzienność oświeconych, t. 1: Przyjemności, pasje i upodobania, red. B. Mazurkowa, Katowice 2013, s. 127-145.

A nobleman at home.

The decor and furnishings of noble houses in the Zakroczym Land in the second half of the 17 th century and in the 18th century

As a result of a survey of the records from the chancellery of the Zakroczym nobility court, 238 inventories of movables of various types were noted, including 205 probate inventories, 17 trousseau inventories, and 16 other registers, dating from 1677 to 1795 , of which 164 documents were used in further analyses. The analysed inventories indicate that in the discussed area inventories listing movable property were rare legal instruments until almost the end of the 17th century. In the 1680s seven inventories were drawn up and recorded in court registers (in contrast to just a couple in earlier decades), and by the 1690s there were already 22 such inventories.

The set of objects which were used daily inside the residences by the owners and their closest family was similar to that known from other social environments and other regions of the Polish-Lithuanian Commonwealth. The differentiating elements, emphasising the social status, were the raw materials, colours, finishing and ornamentation, as well as the number of objects themselves.

Certain tendencies readily apparent in the analysed period have been identified on the basis of the examined documents. One of these is the gradual disappearance of traditional elements of residential interior decoration, such as oriental textiles used as upholstery and carpets. It was established that the inventory of bedding and bed linen, towels, caskets, and boxes did not change in the 18 th century. Similarly, the custom of storing various items in chests was still alive - chests were listed in $50 \%$ of the records from the second half of the 18th century. During this period we can also observe the trend to separate parts of the space with screens or to cover the beds with canopies. In the second half of the 18th century, storage furniture such as chests were recorded more frequently and their average number almost doubled. The situation was similar in 
the case of table linen. In addition, the average number of tableware tripled, and the frequency of listing and the average number of spoons in the inventories almost doubled. Comparing the two halves of the 18th century, similar observations can also be made with regard to the knives recorded in the discussed sources. An innovation in the second half of this century was undoubtedly the small spoon. Novelty items also appeared in the furniture range - these were primarily round or folding tables, chairs in considerable numbers (six or more), suites composed of a sofa and chairs, and chests of drawers. It is also worth noting (although this topic deserves much wider discussion) the use of crimson fabrics from the 1740s onwards (bedding, screens, furniture upholstery). Silver, although in limited quantities, seems to have been an attribute of the wealthier nobility holding landed offices. In the second half of the 17th century, a few accounts mention spoons made of this metal, whereas larger stocks of silver tableware were in the possession of the Zakroczym nobility in the first half of the 18th century. In the second half of that century, faïence and porcelain vessels appeared on lists of tableware kept in noble residences, in line with the fashion of that time.

The frequency with which items representing different categories of movables appear in the analysed written records is presented in the tables attached to the text.

Translated by Karolina Ploska

Proofread by Rebecca Gorzynska 